\title{
Natural dolomitic limestone-catalyzed synthesis of benzimidazoles, dihydropyrimidinones, and highly substituted pyridines under ultrasound irradiation
}

\author{
Kumar Godugu ${ }^{\ddagger 1}$, Venkata Divya Sri Yadala ${ }^{\ddagger 1}$, Mohammad Khaja Mohinuddin Pinjari ${ }^{\ddagger 1}$, \\ Trivikram Reddy Gundala ${ }^{1}$, Lakshmi Reddy Sanapareddy² \\ and Chinna Gangi Reddy Nallagondu*1
}

\author{
Full Research Paper \\ Address: \\ 1Department of Chemistry, Green and Sustainable Synthetic Organic \\ Chemistry Laboratory, Yogi Vemana University, Kadapa-516 005, \\ Andhra Pradesh, India and ${ }^{2}$ Department of Physics, S.V.D. College, \\ Kadapa-516003, Andhra Pradesh, India \\ Email: \\ Chinna Gangi Reddy Nallagondu* - \\ ncgreddy@yogivemanauniversity.ac.in \\ * Corresponding author $\ddagger$ Equal contributors \\ Keywords: \\ benzimidazoles; dihydropyrimidinones; highly substituted pyridines; \\ natural dolomitic limestone; ultrasound irradiation
}

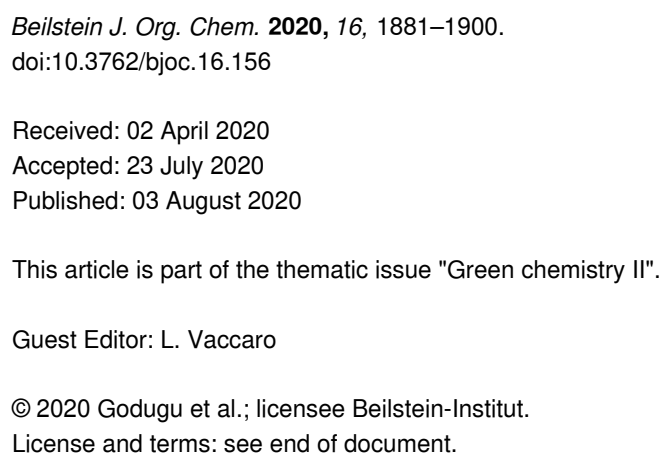

\begin{abstract}
Natural dolomitic limestone (NDL) is employed as a heterogeneous green catalyst for the synthesis of medicinally valuable benzimidazoles, dihydropyrimidinones, and highly functionalized pyridines via $\mathrm{C}-\mathrm{N}, \mathrm{C}-\mathrm{C}$, and $\mathrm{C}-\mathrm{S}$ bond formations in a mixture of ethanol and $\mathrm{H}_{2} \mathrm{O}$ under ultrasound irradiation. The catalyst is characterized by XRD, FTIR, Raman spectroscopy, SEM, and EDAX analysis. The main advantages of this methodology include the wide substrate scope, cleaner reaction profile, short reaction times, and excellent isolated yields. The products do not require chromatographic purification, and the catalyst can be reused seven times. Therefore, the catalyst is a greener alternative for the synthesis of the above N-heterocycles compared to the existing reported catalysts.
\end{abstract}

\section{Introduction}

Nitrogen heterocycles are recognized as "privileged medicinal scaffolds" because these compounds are found in a wide variety of bioactive natural products and pharmaceuticals [1-3]. Among them, benzimidazoles, dihydropyrimidinones, and pyridines have emerged as promising and valuable structural units in many pharmaceutical lead compounds (Figure 1) [4-9]. Hence, there is a great need for the development of a green and sustainable synthetic route to the aforesaid nitrogen-containing heterocycles.

Benzimidazoles are an important class of N-heterocycles due to their potential applications in both biology and medicinal chem- 


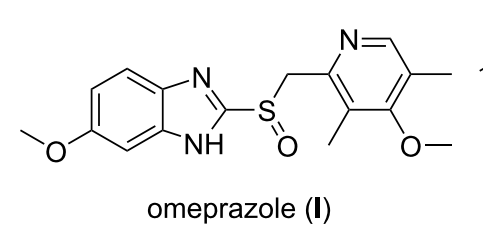<smiles>CCCSc1ccc2[nH]c(NC(=O)OC)nc2c1</smiles><smiles>CCCCNC(=O)n1c(NC(=O)OC)nc2ccccc21</smiles><smiles>c1ccc2[nH]c(-c3cscn3)nc2c1</smiles>

benomyl (III)<smiles>CC1=C(C(=O)OC(C)C)C(c2cccc([N+](=O)[O-])c2)N(C(N)=O)C(=O)N1</smiles>

antihypertensive activity<smiles>N#Cc1c(N)nc(Sc2ccc(Cl)cc2)c(C#N)c1-c1ccccc1</smiles>

IX

pyridines IX-X

identified as active in mice ScN2a cells<smiles>CCOC(=O)C1=C(C)NC(=S)N[C@H]1c1cccc(O)c1</smiles>

(S)-monastrol anticancer activity<smiles>[X]C(=O)NC(C(C(=O)NC)=C(C)NC)c1cccc([N+](=O)[O-])c1</smiles>

$\mathrm{X}=\mathrm{O}, \mathrm{S}$

VII antioxidant activity<smiles>[R]CN(C)C(C)C</smiles>

thiabendazole (IV)<smiles>[X][C]c1c(Sc2ccc(Cl)cc2)nc(N)c(C#N)c1-c1cccs1</smiles>

$\mathbf{x}$<smiles>[X]c1nc(N)c(C)c(Br)c1CSc1ncc[nH]1</smiles>

pyridines $\mathbf{X I}-\mathbf{X I I}$

human adenosine receptors<smiles>Cc1c(SCCO)nc(N)c(C#N)c1Br</smiles>

XII

Figure 1: The benzimidazoles I-IV, dihydropyrimidinones/-thiones V-VIII, and 2-amino-4-aryl-3,5-dicarbonitrile-6-sulfanylpyridines IX-XII as medicinally privileged structures.

istry [10-13]. These compounds are used in the treatment of diseases, such as obesity, ischemia-reperfusion injury, hypertension, etc. [14-16]. In addition, these compounds are important intermediates in a variety of organic reactions and key elements in many functional materials [17-19]. Because of their potential utility, a huge number of synthetic protocols has been developed for the preparation of benzimidazole derivatives. The most common method for the preparation of benzimidazoles is the reaction between $o$-phenylenediamines and carboxylic acids $[20,21]$. Another general synthetic route reported is the condensation reaction of $o$-phenylenediamine with aldehydes in the presence of various catalysts, such as Zn-proline, trimethylsilyl chloride (TMSCl), Amberlite ${ }^{\circledR}$ IR-120, indion 190, trifluoroethanol, $\mathrm{YCl}_{3}, \mathrm{HClO}_{4}-\mathrm{SiO}_{2}, \mathrm{MMZ}_{\mathrm{Y}}$ zeolite, $\mathrm{Er}(\mathrm{OTf})_{3}$, etc. [2230].

Developments in already established multicomponent reactions (MCRs) are interesting topics in organic synthesis. For instance, the Biginelli reaction is a renowned and tunable MCR to synthesize the pharmacologically active 3,4-dihydropyrimidin2-(1H)-ones (DHPMs, Biginelli products) [31]. These compounds occupy an important position in the fields of natural products and synthetic organic chemistry owing to their potential pharmacological properties [32-37]. A wide variety of Brønsted acids and Lewis acids are employed as efficient cata- lysts for the Biginelli reaction [38-47]. In addition, some transition metal-based catalysts and a few nonacidic inorganic salts are also utilized as catalysts for the above reaction [48-58]. Only few basic catalysts, such as $t$ - $\mathrm{BuOK}, \mathrm{Ph}_{3} \mathrm{P}$, and L-proline are reported for the Biginelli reaction [59-61].

2-Amino-4-aryl-3,5-dicarbonitrile-6-sulfanylpyridines have gained considerable attention due to their wide-ranging biological activities $[62,63]$. The most common synthetic route for the preparation of 2-amino-4-aryl-3,5-dicarbonitrile-6-thiopyridines is the condensation reaction of aldehydes, malononitrile, and thiols in the presence of a variety of catalysts [64-72]. Though the reported methods are efficient to provide the desired 1,2-disubstituted benzimidazoles, dihydropyrimidinones/-thiones and 2-amino-4-aryl-3,5-dicarbonitrile-6sulfanylpyridines, there are still some drawbacks, which include the use of expensive catalysts, the preparation of the catalyst, long reaction times, the limited substrate scope, and complicated work-up processes; further, the products require chromatographic purification.

The mineral NDL is an irregular combination of calcium and magnesium carbonate. It is water-insoluble, environmentally benevolent, inexpensive, nontoxic, and abundant in nature. Further, dolomite is used as a heterogeneous green catalyst in 
very few organic transformations, such as Knoevenagel, Michael-Henry, and transesterification reactions [73,74]. To the best of our knowledge, there are no reports on the NDL-catalyzed synthesis of aforesaid N-heterocycles under ultrasonic irradiation (USI).

In this paper, we wish to report the use of NDL as a heterogeneous green catalyst for the synthesis of the 1,2-disubstituted benzimidazoles $\mathbf{3}$, the dihydropyrimidinones/-thiones $\mathbf{7}$, and the 2-amino-4-(hetero)aryl-3,5-dicarbonitrile-6-sulfanylpyridines 11 via $\mathrm{C}-\mathrm{N}, \mathrm{C}-\mathrm{C}$, and $\mathrm{C}-\mathrm{S}$ bond-forming reactions, respectively, in a mixture of EtOH and $\mathrm{H}_{2} \mathrm{O}$ 1:1 under ultrasonic irradiation (Scheme 1).

\section{Results and Discussion Geological background of the NDL catalyst}

The NDL catalyst was collected from V. Kothapalli village (N 1431'54”, E 78 02'58”), Vemula Mandal of the Cuddapah district, Rayalaseema, Andhra Pradesh, India. The rock formation in the mineralized area of this village belongs to the Vempalli Formation (VF) of the Papaghni group of the lower Cuddapah Supergroup in the Cuddapah Basin (CB). The carbonate minerals, such as limestone and dolomite, are the most abundant ones and common sedimentary rocks present in this area.

\section{Catalyst characterization}

The NDL catalyst was ground into a fine powder and then sieved in a 200-mesh sieve. The chemical composition of the catalyst was determined by standard quantitative analysis. The basic strength of the catalyst was analyzed by using Hammett indicators. The catalyst was characterized by XRD, IR, Raman, SEM, and EDAX analysis.

The chemical composition of the NDL was determined by adopting a standard quantitative analysis [75]. The obtained results are summarized in Table 1.

The basic strength of the NDL catalyst $\left(\mathrm{H}_{-}\right)$was measured using Hammett indicators, namely bromothymol blue $\left(H_{-}=7.2\right)$, phenolphthalein $\left(H_{-}=9.8\right), 2$,4-dinitroaniline $\left(H_{-}=15.0\right)$, and nitroaniline $\left(H_{-}=18.4\right)$ as Hammett indicators. In each case, $5 \mathrm{~mL}$ of a methanolic solution of the Hammett indicator was added to $50 \mathrm{mg}$ of the catalyst, shaken

i)
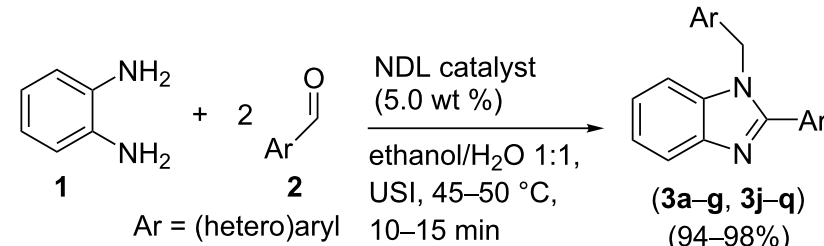

(3a-g, 3j-q)

(94-98\%)

15 examples

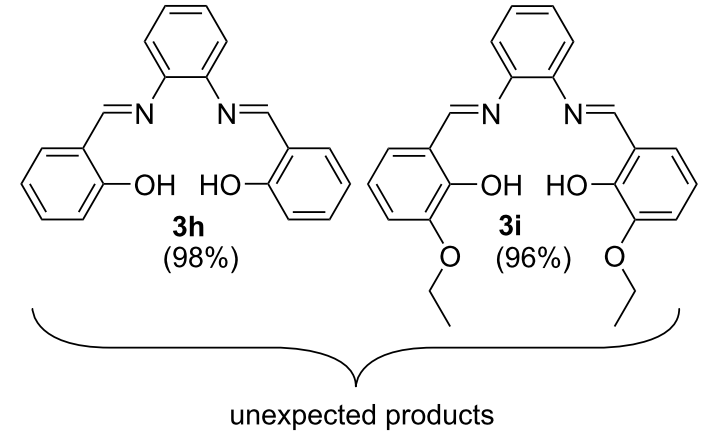

ii)
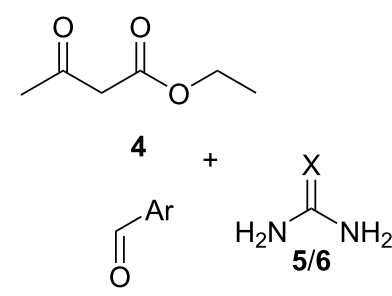

NDL catalyst (5.0 wt \%)

ethanol/ $\mathrm{H}_{2} \mathrm{O} 1: 1$, USI, $45-50{ }^{\circ} \mathrm{C}, 10-20 \mathrm{~min}$<smiles>[X]C1=C(C(=O)OCC)C(Br)NC(C)=C1[Te]</smiles>

$\mathrm{Ar}=($ hetero $)$ aryl

iii)

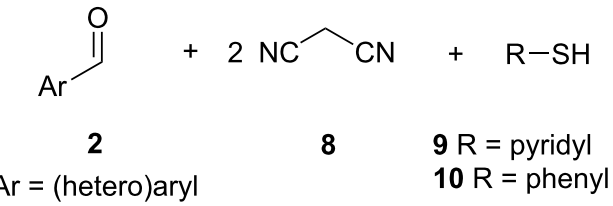

NDL catalyst (5.0 wt \%) ethanol/ $/ \mathrm{H}_{2} \mathrm{O} 1: 1$, USI 45-50 ${ }^{\circ} \mathrm{C}, 30-45 \mathrm{~min}$

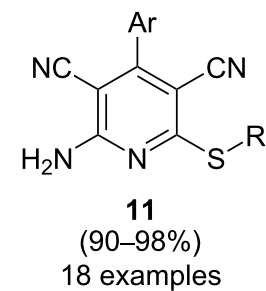




\begin{tabular}{|c|c|c|c|c|c|c|c|c|c|}
\hline component & LOI & $\mathrm{CaO}$ & $\mathrm{MgO}$ & $\mathrm{SiO}_{2}$ & $\mathrm{Al}_{2} \mathrm{O}_{3}$ & $\mathrm{Fe}_{2} \mathrm{O}_{3}$ & $\mathrm{SO}_{3}$ & $\mathrm{Na}_{2} \mathrm{O}$ & $\mathrm{K}_{2} \mathrm{O}$ \\
\hline$\%$ & 38.90 & 41.84 & 9.90 & 7.3 & 0.94 & 0.30 & 0.24 & 0.28 & 0.05 \\
\hline
\end{tabular}

well, and then allowed to equilibrate for $2 \mathrm{~h}$. No color variation of the indicators was observed. The study revealed that the basic strength of the NDL catalyst was weaker than the bromothymol blue indicator, i.e., $\mathrm{H}_{-}<7.2$. Hence, the NDL catalyst is a mild base, and it can activate both nucleophilic and electrophilic groups [73]. Further, the amount of basic sites on the catalyst was estimated by titration using a standard benzoic acid solution and bromothymol blue indicator. Initially, the catalyst $(50 \mathrm{mg})$ was stirred with the methanolic solution of the indicator $(5 \mathrm{~mL}$ ) for $30-40 \mathrm{~min}$, and then, the mixture was titrated with a $0.02 \mathrm{M}$ benzoic acid solution. From the titer values of the benzoic acid solution, the amount of the basic sites was found to be $0.033 \mathrm{mmol} / \mathrm{g}$.

The powder XRD pattern of the NDL catalyst is shown in Figure 2. The diffraction peaks at $2 \theta=23.16,29.51,31.05$, $36.02,38.07,39.40,43.0,47.2,47.5,48.5,56.6,57.6,60.9$, and $64.8^{\circ}$ were attributed to the (012), (104), (006), (015), (110), (113), (021), (024), (018), (116), (211), (122), (214), and (030) plane, respectively, of the NDL catalyst (JCPDS card file
5-586: calcite and 11-78: dolomite) [76,77]. Small quantities of aluminium silicates (kaolinite) and iron oxides were also confirmed by the XRD pattern. The less intense diffraction peaks at $2 \theta=12.3,24.8$, and 37.4 were assigned to the 001,002 , and 003 plane, respectively, of kaolinite (JCPDS card file 14-0164) [78]. The low-intense peaks at $2 \theta=18.6,26.1,44.7,54.6,58.4$, and 63.0 were ascribed to the $111,211,400,422,511$, and 440 plane, respectively, of iron oxides (JCPDS card file 39-1346 and JCPDS card file 19-629) [79,80]. The above results were supported by FTIR and Raman characterization studies of the catalyst (vide infra).

The FTIR spectrum of the catalyst is shown in Figure 3. In the IR spectrum, two distinct vibrational modes of the carbonates, i.e., out-of-plane bending and in-plane bending, were observed at $875 \mathrm{~cm}^{-1}\left(v_{2}\right)$ and $720 \mathrm{~cm}^{-1}\left(v_{4}\right)$, respectively. The bands at $1086 \mathrm{~cm}^{-1}$ and $1424 \mathrm{~cm}^{-1}$ were ascribed to a symmetric stretching vibration $\left(v_{1}\right)$ and an asymmetric stretching vibration $\left(v_{3}\right)$ of the carbonate group, respectively. The combined bands of the carbonate group, i.e., $v_{1}+v_{4}$ and $v_{1}+v_{3}$ were observed at

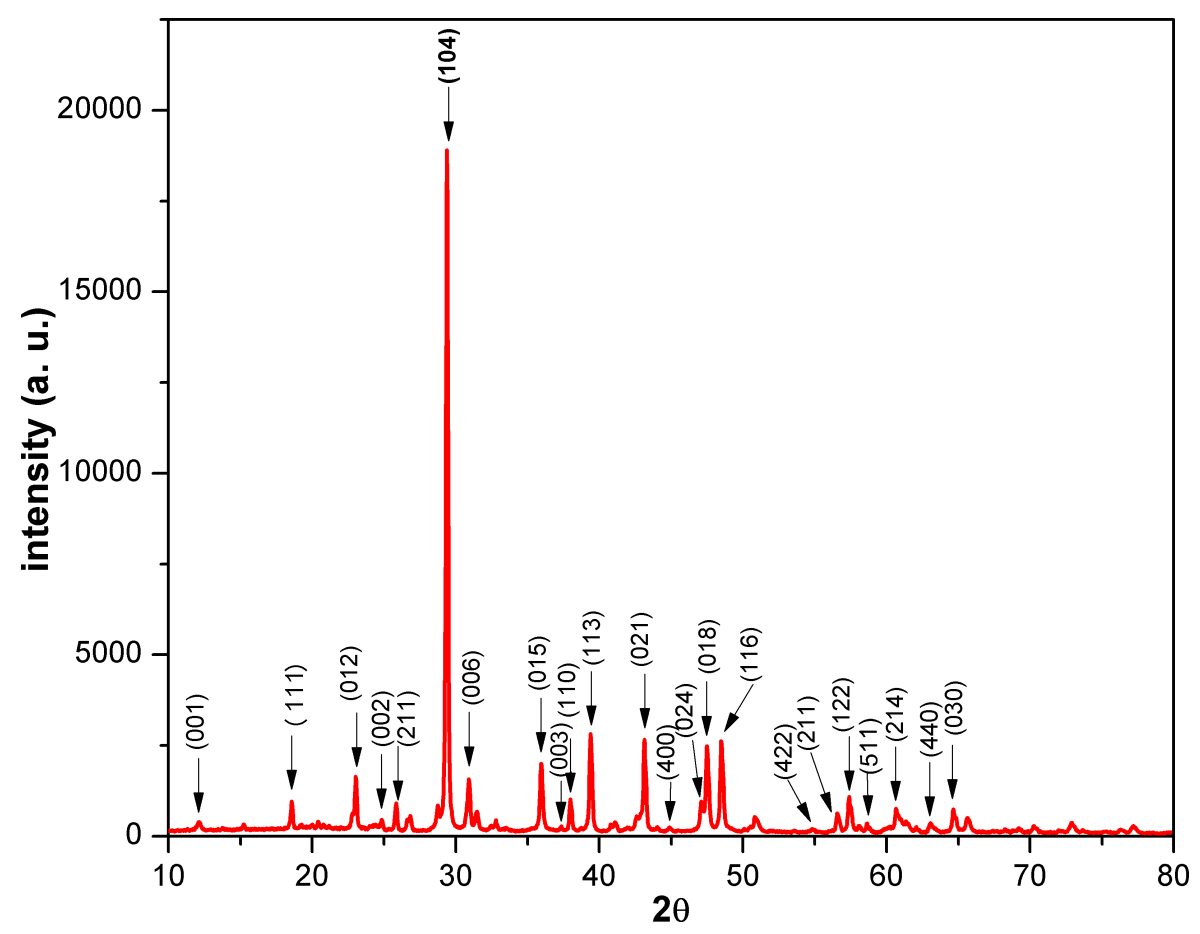

Figure 2: XRD pattern of the NDL catalyst. 


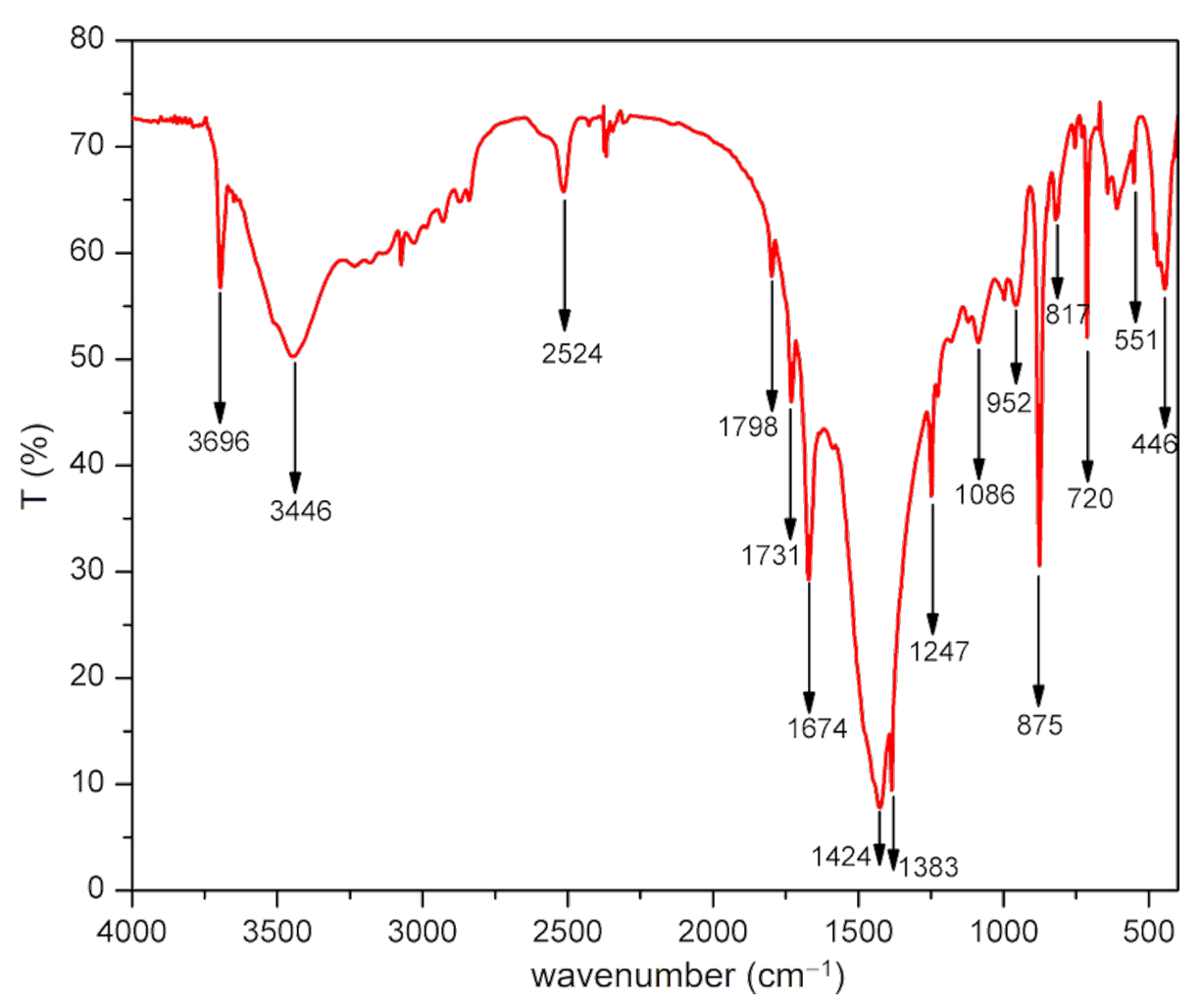

Figure 3: FTIR spectrum of the NDL catalyst.

1798 and $2524 \mathrm{~cm}^{-1}$, respectively [76,77,81]. The IR bands at $3446 \mathrm{~cm}^{-1}$ (broad) and $1674 \mathrm{~cm}^{-1}$ (sharp) indicated the presence of stretching and bending vibrations of water [82]. The impurities aluminium silicate and iron oxides in the NDL were confirmed by IR spectroscopy. The peaks located at 446,551 , $817,952,1247$, and $1383 \mathrm{~cm}^{-1}$ were attributed to the $\mathrm{Si}-\mathrm{O}$ bending, Fe-O stretching, Al-O-Si stretching, Si-OH bending, $\mathrm{Si}-\mathrm{O}$ stretching, and Al-O bending, respectively [83,84]. Further, the sharp band at $3696 \mathrm{~cm}^{-1}$ indicated the presence of a well-ordered kaolinite structure [76].

The Raman spectrum of the NDL catalyst is shown in Figure 4. The band at $1092 \mathrm{~cm}^{-1}$ was attributed to the symmetric stretching vibration $\left(v_{1}\right)$ of the carbonate group. The peaks at 714 and $1435 \mathrm{~cm}^{-1}$ were assigned to a symmetric bending $\left(v_{4}\right)$ and an asymmetric stretching vibration $\left(v_{3}\right)$ of carbonate. The weak peak at $1750 \mathrm{~cm}^{-1}$ was due to the combined band $v_{1}+v_{4}$. The bands at 152 and $278 \mathrm{~cm}^{-1}$ were ascribed to the external vibrations of the carbonate group [76,77]. The presence of aluminium silicates and iron oxides present in the sample were confirmed by Raman spectroscopy. The bands at 418, 578, 753, and $985 \mathrm{~cm}^{-1}$ were assigned to $\mathrm{Al}-\mathrm{O}$ bending, $\mathrm{Si}-\mathrm{O}$ rocking, Al-O stretching, and $\mathrm{Si}-\mathrm{OH}$ stretching vibrations, respectively [85]. Further, a very weak peak at $618 \mathrm{~cm}^{-1}$ was attributed to iron oxide, and a very broad peak at $1312 \mathrm{~cm}^{-1}$ (magnon) indi- cated the presence of magnetically ordered ferromagnetic or antiferromagnetic iron oxides [86]. The observed Raman and infrared vibrational bands of the NDL were in good agreement with the reported values. The minor shift in the band positions might be due to the presence of trace metal contents and impurities.

The morphology of the NDL catalyst was analyzed by scanning electron microscopy (Figure 5). The SEM images revealed that the morphology of the NDL catalyst consists of irregular shapes and sizes with a random dispersion. Further, the elemental composition of the NDL catalyst was determined by EDAX analysis (Figure 6).

The catalytic activity of the NDL for the synthesis of the 1,2disubstituted benzimidazoles $\mathbf{3}$, the dihydropyrimidinones/thiones 7, and the 2-amino-4-(hetero)aryl-3,5-dicarbonitrile-6sulfanylpyridines $\mathbf{1 1}$ was investigated, along with other, commercially available catalysts.

\section{NDL-catalyzed synthesis of 1,2-disubtituted benzimidazoles 3}

To check the catalytic activity of the NDL, initially, $o$-phenylenediamine (1) and benzaldehyde (2a) were chosen as model substrates to optimize the reaction conditions for the syn- 


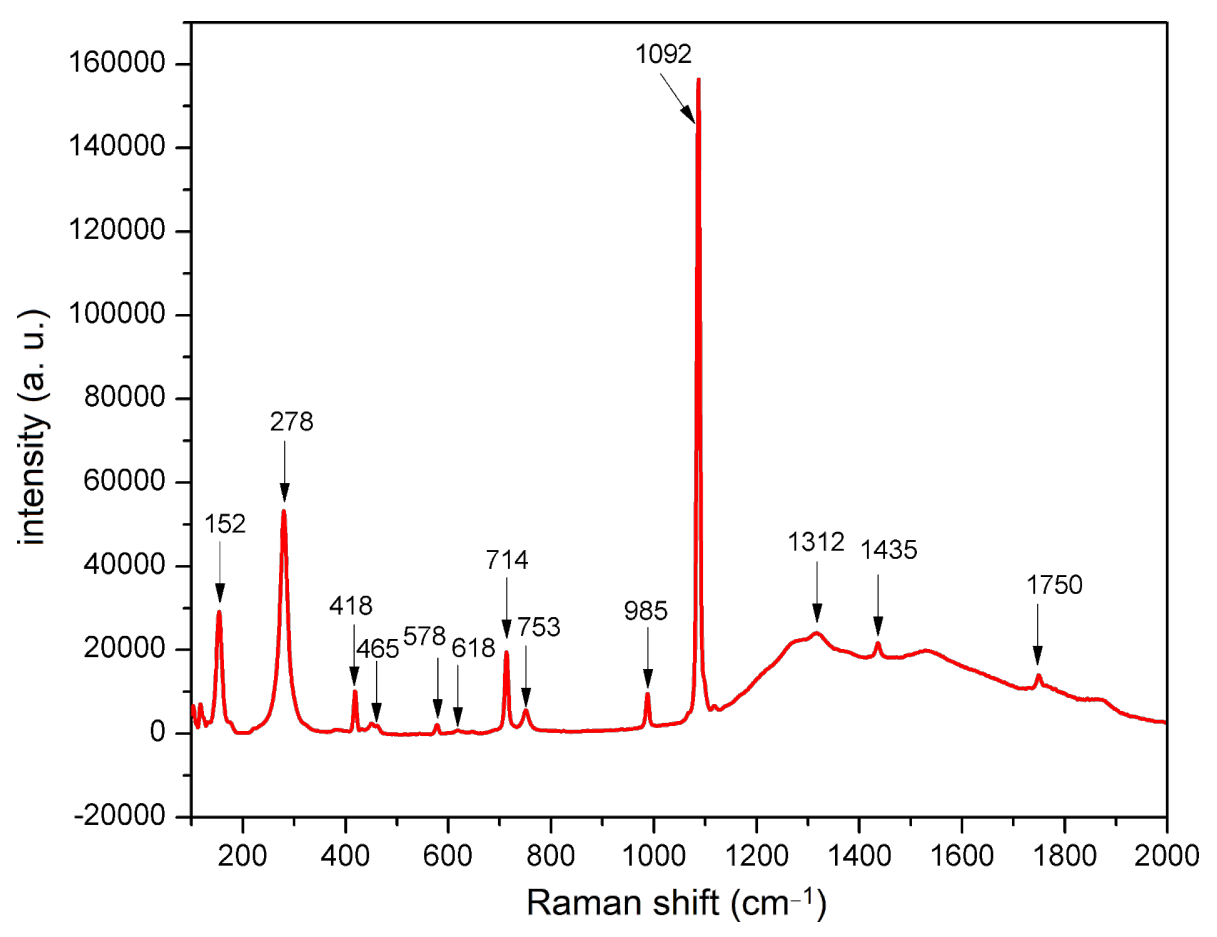

Figure 4: Raman spectrum of the NDL catalyst.
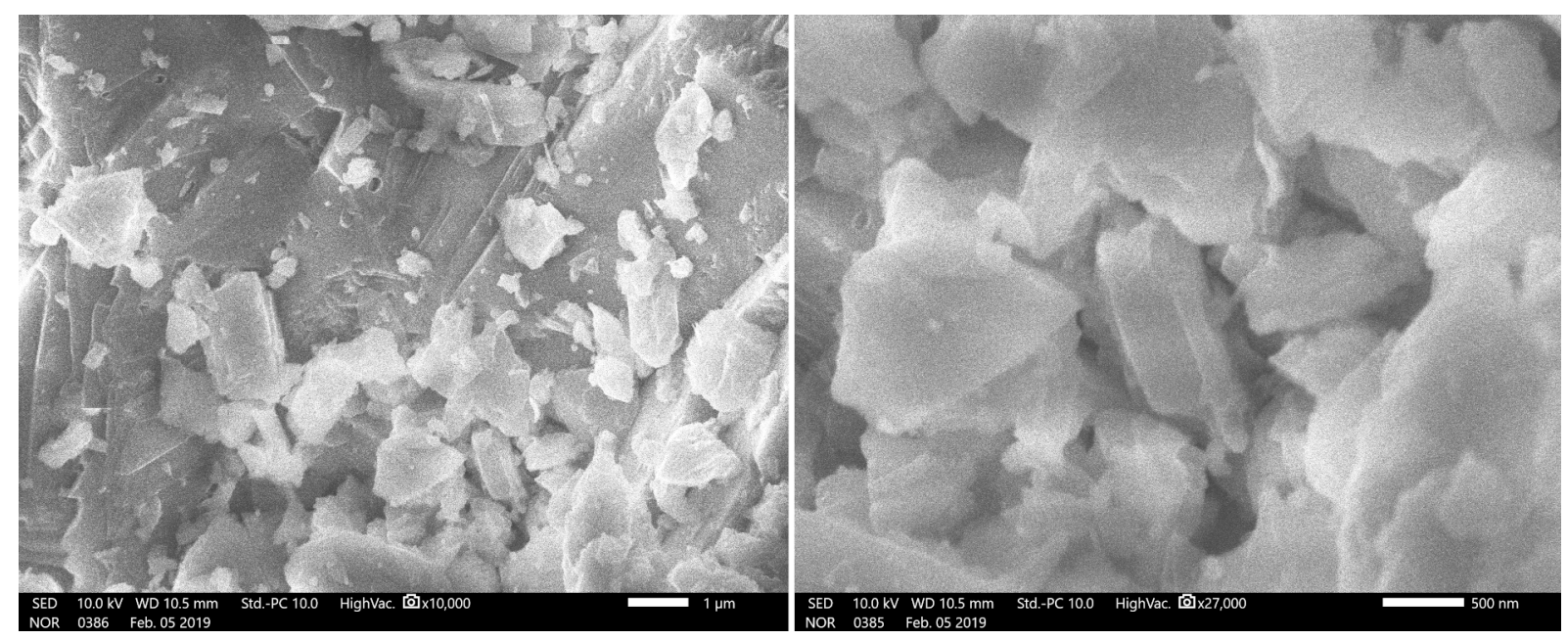

Figure 5: SEM images of the NDL catalyst.

thesis of 1-benzyl-2-phenyl-1H-benzo[d]imidazole (3a). At first, a control experiment was conducted by using model substrates, $\mathbf{1}$ and $\mathbf{2 a}$, in $\mathrm{H}_{2} \mathrm{O}$ in the absence of catalyst under ultrasound irradiation for $60 \mathrm{~min}$ at $45-50{ }^{\circ} \mathrm{C}$. It was found that the reaction did not proceed in the absence of a catalyst (Table 2, entry 1). To achieve the target compound 3a, the same reaction was repeated by employing various catalysts (2.5 wt \%), such as $\mathrm{Fe}_{2} \mathrm{O}_{3}, \mathrm{Al}_{2} \mathrm{O}_{3}, \mathrm{KF}$-alumina, dolomitic limestone, triethylamine, pyridine, and DABCO in different solvents, such as water, acetone, $\mathrm{iPrOH}, \mathrm{EtOH}$, and $\mathrm{EtOH} / \mathrm{H}_{2} \mathrm{O}$ 1:1 (Table 2, entries 2-8) under ultrasound irradiation at $45-50{ }^{\circ} \mathrm{C}$. From this study, it was observed that the NDL (2.5 wt \%) was the best option, which gave the target compound $3 \mathbf{a}$ in a high yield (85\%) in a mixture of EtOH and $\mathrm{H}_{2} \mathrm{O}$ 1:1 under ultrasound irradiation for $30 \mathrm{~min}$ at $45-50{ }^{\circ} \mathrm{C}$ (Table 2, entry 5). The other catalysts, $\mathrm{Fe}_{2} \mathrm{O}_{3}, \mathrm{Al}_{2} \mathrm{O}_{3}, \mathrm{KF}$-alumina, triethylamine, pyridine, and 


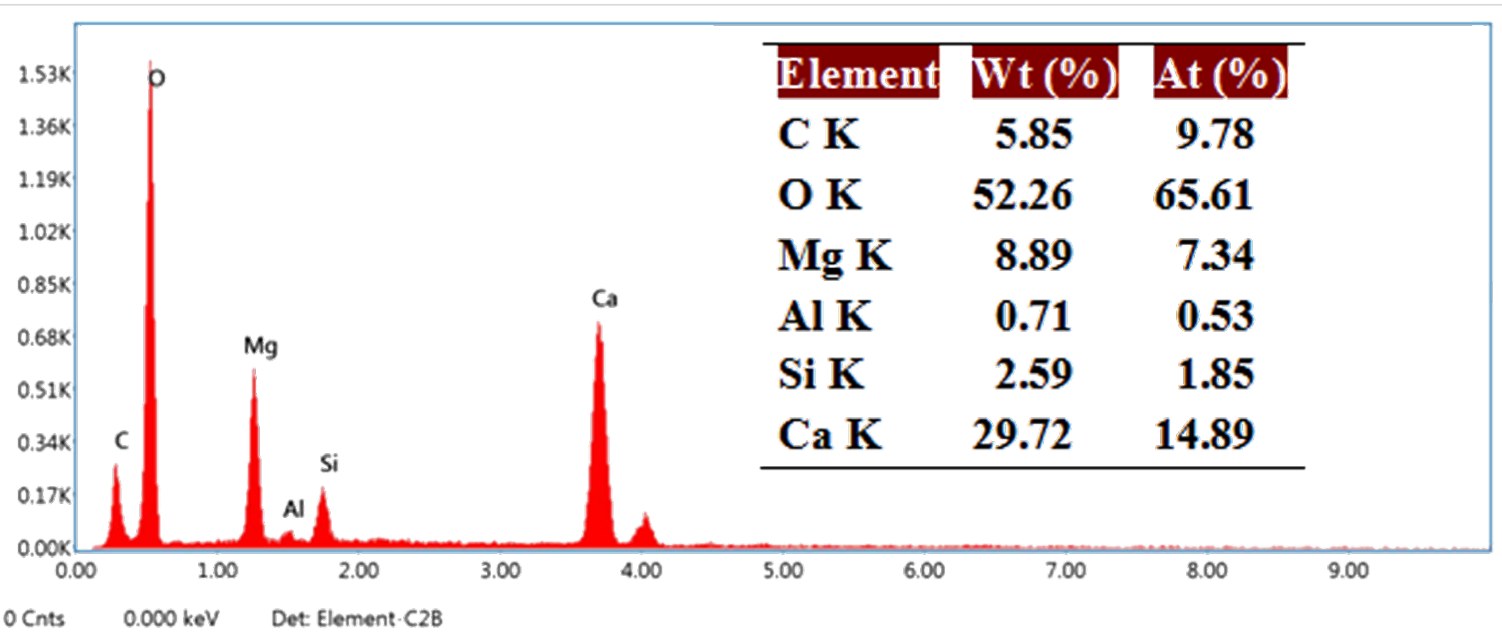

Figure 6: EDAX analysis of the NDL catalyst.

Table 2: Optimization of the reaction conditions. ${ }^{\text {a }}$

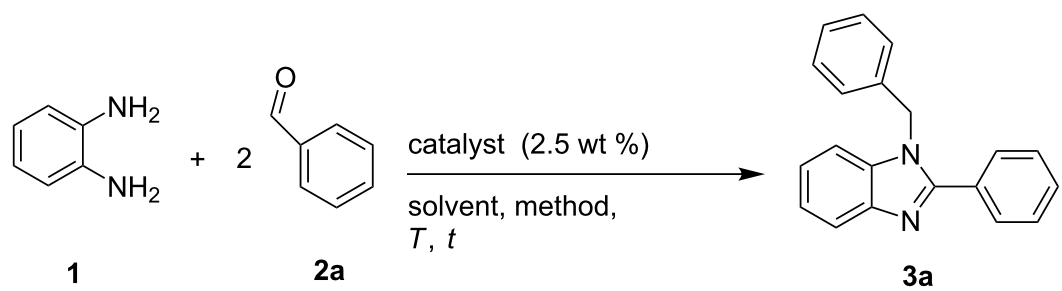

\begin{tabular}{|c|c|c|c|c|c|c|c|}
\hline & & & & & & & \\
\hline \multirow[t]{2}{*}{ entry } & \multirow{2}{*}{$\begin{array}{l}\text { catalyst } \\
(2.5 \text { wt \%) }\end{array}$} & \multirow[t]{2}{*}{ solvent } & \multirow[t]{2}{*}{ product } & \multicolumn{2}{|c|}{ conventional method ${ }^{b}$} & \multicolumn{2}{|l|}{$\mathrm{USI}^{\mathrm{C}}$} \\
\hline & & & & $t(\min )$ & yield $^{d}(\%)$ & $t(\min )$ & yield $^{d}(\%)$ \\
\hline
\end{tabular}

\begin{tabular}{|c|c|c|c|c|c|c|c|}
\hline $1^{e}$ & no catalyst & $\mathrm{H}_{2} \mathrm{O}$ & $3 a$ & 180 & - & 60 & - \\
\hline \multirow[t]{5}{*}{2} & $\mathrm{Fe}_{2} \mathrm{O}_{3}$ & $\mathrm{H}_{2} \mathrm{O}$ & $3 a$ & 60 & 10 & 30 & 15 \\
\hline & & acetone & & 60 & - & 30 & - \\
\hline & & iPrOH & & 60 & 10 & 30 & 20 \\
\hline & & $\mathrm{EtOH}$ & & 60 & 15 & 30 & 20 \\
\hline & & $\mathrm{EtOH} / \mathrm{H}_{2} \mathrm{O} 1: 1$ & & 60 & 20 & 30 & 25 \\
\hline \multirow[t]{5}{*}{3} & $\mathrm{Al}_{2} \mathrm{O}_{3}$ & $\mathrm{H}_{2} \mathrm{O}$ & $3 a$ & 60 & 20 & 30 & 20 \\
\hline & & acetone & & 60 & - & 30 & - \\
\hline & & iPrOH & & 60 & 15 & 30 & 20 \\
\hline & & $\mathrm{EtOH}$ & & 60 & 25 & 30 & 25 \\
\hline & & $\mathrm{EtOH} / \mathrm{H}_{2} \mathrm{O} 1: 1$ & & 60 & 30 & 30 & 40 \\
\hline \multirow[t]{5}{*}{4} & KF-alumina & $\mathrm{H}_{2} \mathrm{O}$ & $3 a$ & 60 & 30 & 30 & 30 \\
\hline & & acetone & & 60 & - & 30 & - \\
\hline & & iPrOH & & 60 & 25 & 30 & 30 \\
\hline & & $\mathrm{EtOH}$ & & 60 & 40 & 30 & 35 \\
\hline & & $\mathrm{EtOH} / \mathrm{H}_{2} \mathrm{O} 1: 1$ & & 60 & 50 & 30 & 40 \\
\hline \multirow[t]{5}{*}{5} & NDL & $\mathrm{H}_{2} \mathrm{O}$ & $3 a$ & 60 & 55 & 30 & 65 \\
\hline & & acetone & & 60 & - & 30 & - \\
\hline & & iPrOH & & 60 & 35 & 30 & 45 \\
\hline & & $\mathrm{EtOH}$ & & 60 & 60 & 30 & 75 \\
\hline & & $\mathrm{EtOH} / \mathrm{H}_{2} \mathrm{O} 1: 1$ & & 60 & 70 & 30 & 85 \\
\hline
\end{tabular}


Table 2: Optimization of the reaction conditions. ${ }^{a}$ (continued)

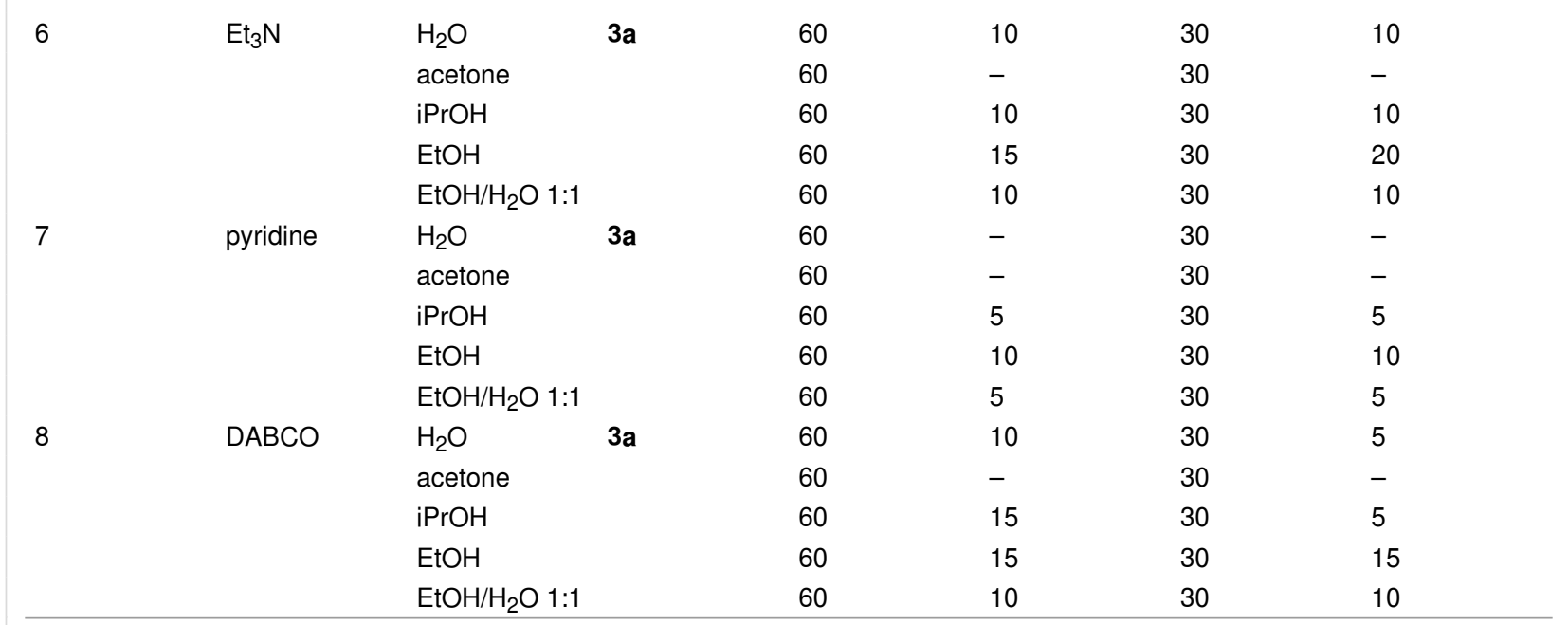

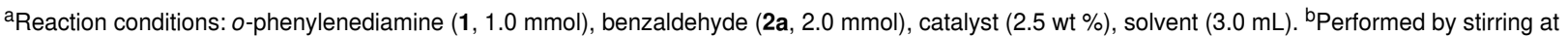
reflux (entries 2-8). ${ }^{\mathrm{C} U S I}$ method performed at $45-50{ }^{\circ} \mathrm{C}$. d Isolated yield. ${ }^{e}$ Conventional method performed by stirring at $45-50{ }^{\circ} \mathrm{C}$.

DABCO, provided a moderate to low yield of the product 3a (Table 2, entries 2-4 and 6-8). The aforesaid reaction was performed under conventional stirring of the model substrates 1 and $2 \mathrm{a}$ in $\mathrm{H}_{2} \mathrm{O}$ in the absence of catalyst for $180 \mathrm{~min}$ at $45-50{ }^{\circ} \mathrm{C}$. It was observed that the reaction did not proceed in the absence of a catalyst (Table 2, entry 1 ). Further, when the reaction temperature was raised from $45-50{ }^{\circ} \mathrm{C}$ to reflux, a very low yield $(10 \%)$ of the product 3a was obtained after $120 \mathrm{~min}$. Next, the reaction was repeated in the presence of different catalysts and solvents at reflux under conventional reaction conditions as mentioned in Table 2. The study revealed that the NDL in a mixture of EtOH and $\mathrm{H}_{2} \mathrm{O} 1: 1$ afforded a moderate yield $(70 \%)$ of the product $\mathbf{3 a}$ (Table 2, entry 5), whereas the other catalysts, in various solvents, provided lower yields under similar reaction conditions (Table 2, entries 2-4 and 6-8). From the above observations, it was concluded that the ultrasound irradi- ation method is better than the conventional method in giving the maximum yield of $\mathbf{3 a}$.

Next, the amount of catalyst was varied (using 2.5, 5.0, 7.5, 10.0 , and $12.5 \mathrm{wt} \%$, respectively,) to improve the yield of $\mathbf{3 a}$ (Table 3). The study revealed that $5.0 \mathrm{wt} \%$ of the NDL was the best option to get the highest yield of the product 3a (98\%) in a short reaction time (10 $\mathrm{min}$, Table 3 , entry 3$)$. It was also noticed that the same yield was obtained with an increasing amount of the catalyst, i.e., 7.5, 10.0, and $12.5 \mathrm{wt} \%$ (Table 3, entries 4-6).

In order to demonstrate the effect of the temperature on the course of the model reaction, the control experiment was performed at different temperature ranges (30-35, 35-40, 40-45, and $45-50{ }^{\circ} \mathrm{C}$ ) by using the model substrates $\mathbf{1}$ and $\mathbf{2 a}$ in the

\begin{tabular}{|c|c|c|c|c|c|}
\hline entry & NDL (wt \%) & solvent & $t(\min )$ & product & yield ${ }^{\mathrm{b}}(\%)$ \\
\hline 1 & 2.5 & $\mathrm{EtOH} / \mathrm{H}_{2} \mathrm{O} 1: 1$ & 30 & $3 a$ & 85 \\
\hline 2 & 2.5 & $\mathrm{EtOH} / \mathrm{H}_{2} \mathrm{O} 1: 1$ & 10 & $3 a$ & 75 \\
\hline 3 & 5.0 & $\mathrm{EtOH} / \mathrm{H}_{2} \mathrm{O} 1: 1$ & 10 & $3 a$ & 98 \\
\hline 4 & 7.5 & $\mathrm{EtOH} / \mathrm{H}_{2} \mathrm{O} 1: 1$ & 10 & $3 a$ & 98 \\
\hline 5 & 10.0 & $\mathrm{EtOH} / \mathrm{H}_{2} \mathrm{O} 1: 1$ & 10 & $3 a$ & 98 \\
\hline 6 & 12.5 & $\mathrm{EtOH} / \mathrm{H}_{2} \mathrm{O} 1: 1$ & 10 & $3 a$ & 98 \\
\hline
\end{tabular}

aReaction conditions: o-phenylenediamine (1, $1.0 \mathrm{mmol})$, benzaldehyde (2a, $2.0 \mathrm{mmol})$, NDL (2.5 to $12.5 \mathrm{wt} \%)$, EtOH/ $\mathrm{H}_{2} \mathrm{O} 1: 1(3.0 \mathrm{~mL})$, ultrasound irradiation at $45-50^{\circ} \mathrm{C}$. b Isolated yield. 
presence of $5.0 \mathrm{wt} \%$ of the NDL in a mixture of ethanol and water 1:1 for 10 min under both conventional stirring and ultrasound irradiation. The obtained results are presented in Table 4. It was observed that the reaction proceeded with an improved yield of 3a (70-98\%) by increasing the temperature range from $30-35$ to $45-50{ }^{\circ} \mathrm{C}$ with an ultrasound irradiation method (Table 4, entries 1-4). Under conventional stirring, the yield of the product 3a increased from low to moderate when the reaction temperature was raised from $30-35{ }^{\circ} \mathrm{C}$ to reflux (Table 4 , entries 1-5). From the results, it was concluded that a temperature of $45-50{ }^{\circ} \mathrm{C}$ is the optimum temperature to obtain the maximum yield of the desired product $\mathbf{3 a}$ within a short reaction time (10 $\mathrm{min}$ ) under ultrasound irradiation (Table 4, entry 4).

To demonstrate the generality and substrate scope of the present method, a variety of (hetero)aromatic aldehydes was investigated. The obtained results are presented in Table 5. o-Phenylenediamine (1) reacted well with benzaldehyde (2a) to obtain the corresponding product 3a with $98 \%$ yield (Table 5, entry 1 ). The reactions of $o$-phenylenediamine (1) with substituted benzaldehydes having activating groups (4-Me: $\mathbf{2 b}, 4-t-\mathrm{Bu}: \mathbf{2 c}$, 2,4-dimethyl: 2d, 4-OMe: 2e, 3,4-dimethoxy: 2f, 3,4,5trimethoxy: 2g, 4-OH-3-OMe: $\mathbf{2 j}$, and 4-OH-3- $\mathrm{OC}_{2} \mathrm{H}_{5}: \mathbf{2 k}$, Table 5, entries $2-7,10$ and 11$)$, a deactivating group $\left(4-\mathrm{NO}_{2}\right.$ : 2l, Table 5, entry 12), or a halo group (4-F: $\mathbf{2 m}, 4-\mathrm{Cl}: \mathbf{2 n}$, and 4-Br: 2o, Table 5, entries 13-15) in different positions provided good to excellent isolated yields of the corresponding products $\mathbf{3 b}-\mathbf{g}$ and $\mathbf{3 j}-\mathbf{o}$ that ranged from 94 to $98 \%$ in a stipulated period of time, as specified in Table 5. Further, heteroaromatic aldehydes, such as furan-2-aldehyde (2p) and thiophene-2-aldehyde (2q) produced the corresponding products $\mathbf{3 p}$ and $\mathbf{3 q}$ in good isolated yields within a short period of time $(15 \mathrm{~min}$ and $13 \mathrm{~min}$, respectively, Table 5, entries 16 and 17).

However, salicylaldehyde (2h) afforded the unexpected product 2,2'-((1E,1'E)-(1,2-phenylenebis(azanylylidene))bis(methan- ylylidene))diphenol (3h, bisimine I) within $10 \mathrm{~min}$ (Table 5, entry 8). The reaction was expected to proceed through the activation of the carbonyl group of $\mathbf{2 h}$ (of which $2.0 \mathrm{mmol}$ were used) by the cations $\left(\mathrm{Ca}^{2+}\right.$ and $\mathrm{Mg}^{2+}$, respectively) of the NDL. This was followed by a nucleophilic attack of the $\mathrm{NH}_{2}$ groups of $o$-phenylenediamine ( $\mathbf{1}$, of which $1.0 \mathrm{mmol}$ was used), which are activated by the carbonate part of the NDL, followed by dehydration to obtain $\mathbf{3 h}$ (Scheme 2). Due to the mild basic nature of the NDL catalyst, it acts as a dual activator of the electrophilic carbonyl and the nucleophilic $\mathrm{NH}_{2}$ groups. The formation of the bisimine I was confirmed by ${ }^{1} \mathrm{H}$ NMR spectral studies (Figure 7). In the ${ }^{1} \mathrm{H}$ NMR spectrum (DMSO- $d_{6}$ ), the two hydroxy protons of the bisimine I appeared as a broad, strongly downfield-shifted singlet at $\delta 13.19$. The sharp singlet at $\delta 8.66$ indicated the two imine protons $(-\mathrm{N}=\mathrm{CH})$ of the bisimine I. From this result, it was confirmed that the reaction stopped at the bisimine I stage. This was due to the intramolecular hydrogen bonding between the hydrogen atom of the orthohydroxy group and the nitrogen atom of the imine group in a six-membered ring transition state [87]. Similarly, the reaction between 3-ethoxysalicylaldehyde (2i) and $o$-phenylenediamine (1) also ended with the intermediate $6,6^{\prime}-\left(\left(1 E, 1^{\prime} E\right)-(1,2-\right.$ phenylenebis(azanylylidene))bis(methanylylidene))bis(2ethoxyphenol) (3i) stage (Table 4, entry 9 and Supporting Information File 1, Figure S13). Most of the synthesized compounds are known and were identified easily by comparison of the melting point and spectroscopic data with those reported.

\section{NDL-catalyzed synthesis of dihydropyrimidin- ones/-thiones 7}

The results encouraged us to further investigate the catalytic activity of the NDL in the Biginelli reaction. To check the feasibility, a control experiment was performed by using the model substrates benzaldehyde (2a, $1.0 \mathrm{mmol})$, ethyl acetoacetate (4, $1.0 \mathrm{mmol})$, and urea $(5,1.0 \mathrm{mmol})$ in $\mathrm{H}_{2} \mathrm{O}(3.0 \mathrm{~mL})$ in the absence of a catalyst under ultrasound irradiation at $45-50{ }^{\circ} \mathrm{C}$ for $60 \mathrm{~min}$. It was observed that the reaction proceeded with a

\begin{tabular}{|c|c|c|c|c|c|}
\hline entry & $T\left({ }^{\circ} \mathrm{C}\right)$ & product & $t(\min )$ & $\begin{array}{l}\text { conventional method } \\
\text { yield }^{\mathrm{d}}(\%)\end{array}$ & $\begin{array}{l}\text { USIC } \\
\text { yield }^{d}(\%)\end{array}$ \\
\hline 1 & $30-35$ & $3 a$ & 10 & 10 & 70 \\
\hline 2 & $35-40$ & $3 a$ & 10 & 14 & 79 \\
\hline 3 & $40-45$ & $3 a$ & 10 & 20 & 87 \\
\hline 4 & $45-50$ & $3 \mathbf{a}$ & 10 & 26 & 98 \\
\hline $5^{e}$ & reflux & $3 a$ & $10 / 60$ & $35 / 70$ & - \\
\hline
\end{tabular}

aReaction conditions: o-phenylenediamine (1, $1.0 \mathrm{mmol})$, benzaldehyde (2a, $2.0 \mathrm{mmol}), \mathrm{NDL}(5.0 \mathrm{wt} \%)$, EtOH/ $\mathrm{H}_{2} \mathrm{O} 1: 1$ (3.0 mL). ${ }^{\mathrm{b}} \mathrm{Conventional} \mathrm{stir-}$ ring and heating with a silicone oil bath. ${ }^{C}$ Ittrasound irradiation in a water bath. ${ }^{\mathrm{d}}$ Isolated yield. ${ }^{\mathrm{e}}$ Conventional stirring at reflux. 


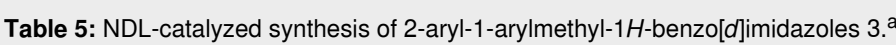

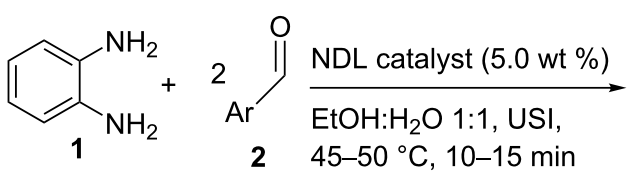

$\mathrm{Ar}=($ hetero) $\operatorname{aryl}$<smiles>[Al]Cn1c([Al])nc2ccccc21</smiles>

$(\mathbf{3} \mathbf{a}-\mathbf{g}$ and $\mathbf{3} \mathbf{j}-\mathbf{q})$ $(94-98 \%)$<smiles>Oc1ccccc1/C=N/c1ccccc1/N=C/c1ccccc1O</smiles>

3h $(98 \%)$

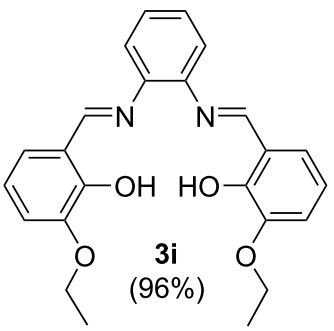

\begin{tabular}{|c|c|c|c|c|c|c|}
\hline \multirow[t]{2}{*}{ entry } & \multirow[t]{2}{*}{$\operatorname{Ar}$} & \multirow[t]{2}{*}{ product } & \multirow[t]{2}{*}{$t(\min )$} & \multirow[t]{2}{*}{ yield $(\%)$} & \multicolumn{2}{|l|}{$\mathrm{mp}\left({ }^{\circ} \mathrm{C}\right)$} \\
\hline & & & & & found & reported \\
\hline 1 & phenyl: $\mathbf{2 a}$ & $3 a$ & 10 & 98 & $128-131$ & $133-134$ [23] \\
\hline 2 & 4-methylphenyl: $\mathbf{2 b}$ & $3 b$ & 10 & 98 & $127-128$ & $128-129$ [23] \\
\hline 3 & 4-tert-butylphenyl: $\mathbf{2 c}$ & $3 c$ & 15 & 94 & $124-125$ & $122-126[25]$ \\
\hline 4 & 2,4-dimethylphenyl: $2 \mathbf{d}$ & 3d & 12 & 96 & $120-122$ & $119-123[25]$ \\
\hline 5 & 4-methoxyphenyl: $\mathbf{2 e}$ & $3 e$ & 11 & 98 & $157-159$ & $158-160[23]$ \\
\hline 6 & 3,4-dimethoxyphenyl: $\mathbf{2 f}$ & $3 f$ & 12 & 95 & $167-169$ & $171-173[24]$ \\
\hline 7 & 3,4,5-trimethoxyphenyl: $\mathbf{2 g}$ & $3 g$ & 15 & 94 & $261-262$ & $262-263$ [22] \\
\hline $8^{b}$ & 2-hydroxyphenyl: $\mathbf{2 h}$ & $3 \mathrm{~h}$ & 10 & 98 & $167-168$ & $160-162[23]$ \\
\hline $9^{b}$ & 2-hydroxy-3-ethoxyphenyl: 2i & $3 \mathbf{i}$ & 12 & 96 & $285-287$ & - \\
\hline 10 & 4-hydroxy-3-methoxyphenyl: $\mathbf{2 j}$ & $3 \mathbf{j}$ & 12 & 96 & $181-183$ & $184-186$ [24] \\
\hline 11 & 4-hydroxy-3-ethoxyphenyl: 2k & $3 k$ & 10 & 97 & 205-207 & $200-201[26]$ \\
\hline 12 & 4-nitrophenyl: 2I & 3I & 10 & 98 & $190-192$ & $189-191$ [23] \\
\hline 13 & 4-fluorophenyl: 2m & $3 m$ & 10 & 98 & $108-109$ & $110-112[23]$ \\
\hline 14 & 4-chlorophenyl: 2n & $3 n$ & 10 & 98 & $138-140$ & $137-139$ [23] \\
\hline 15 & 4-bromophenyl: 20 & 30 & 12 & 96 & $158-160$ & $160-162$ [23] \\
\hline 16 & 2 -furanyl: $2 p$ & $3 p$ & 15 & 95 & $90-92$ & $88-89$ [23] \\
\hline 17 & 2-thienyl: 2q & $3 q$ & 13 & 96 & $149-150$ & $150-152$ [23] \\
\hline
\end{tabular}

aReaction conditions: o-phenylenediamine (1, $1.0 \mathrm{mmol})$, aldehyde $(2,2.0 \mathrm{mmol}), \mathrm{NDL}(5.0 \mathrm{wt} \%), \mathrm{EtOH} / \mathrm{H}_{2} \mathrm{O} 1: 1(3.0 \mathrm{~mL}), \mathrm{USI}, 45-50{ }^{\circ} \mathrm{C}$. ${ }^{\mathrm{b}} \mathrm{The}$ reaction stopped at the bisimine I, i.e., $\mathbf{3 h} / \mathbf{i}$ stage. ${ }^{C}$ Isolated yield.

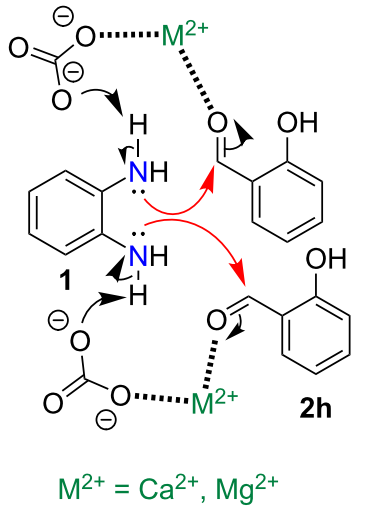

$\mathrm{C}-\mathrm{N}$-bond formation

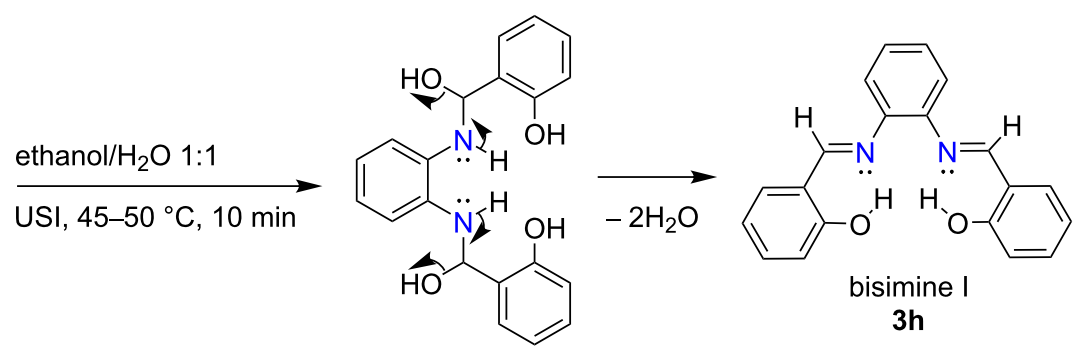




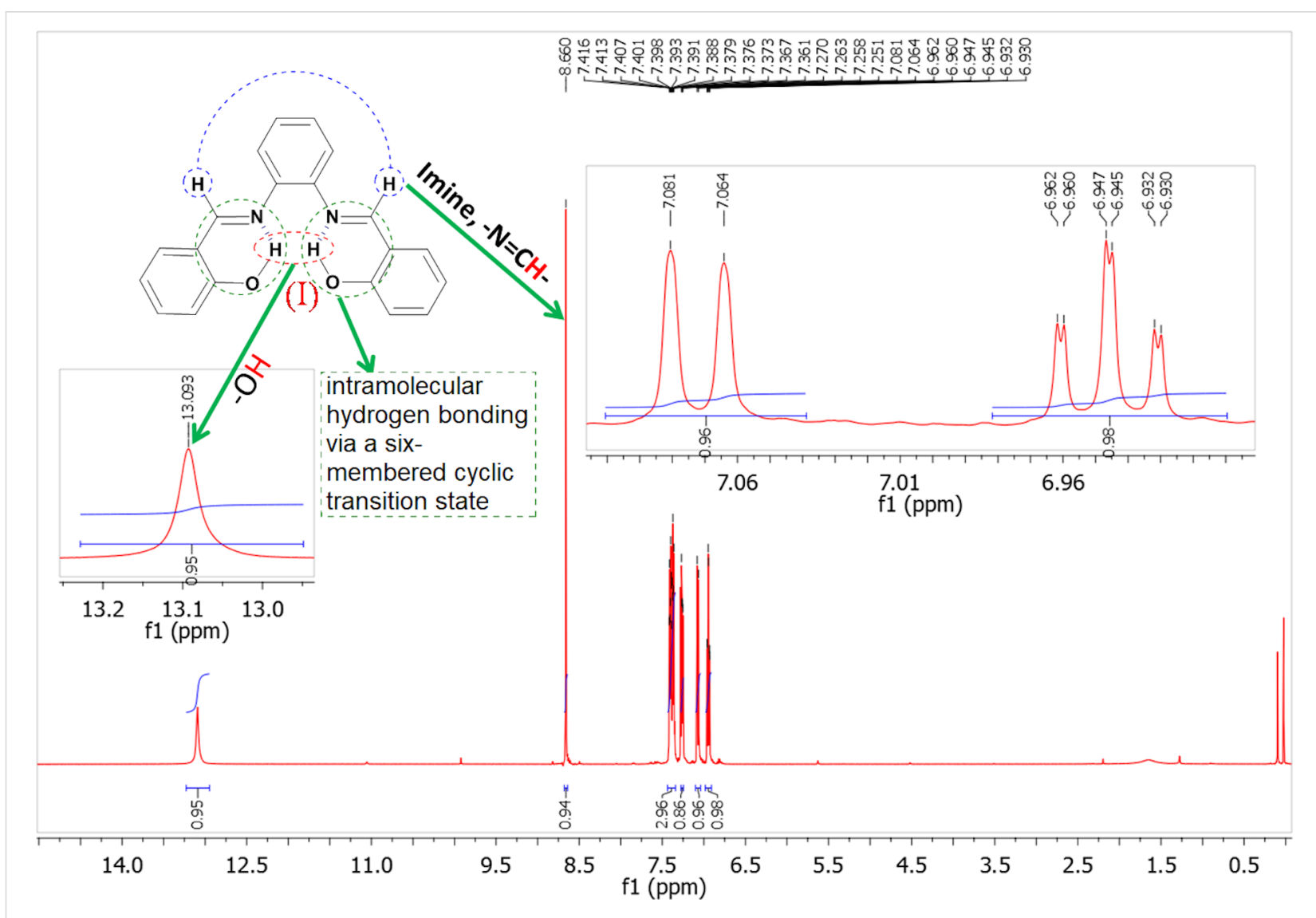

Figure 7: ${ }^{1} \mathrm{H}$ NMR spectrum of 2,2'-((1E,1'E)-(1,2-phenylenebis(azanylylidene))bis (methanylylidene))diphenol (bisimine I, 3h).

very low yield $(20 \%)$ of product $7 \mathbf{a}$. The same reaction was repeated in the presence of the NDL catalyst $(5.0 \mathrm{wt} \%)$ in $\mathrm{EtOH} / \mathrm{H}_{2} \mathrm{O} 1: 1$ under ultrasound irradiation at $45-50{ }^{\circ} \mathrm{C}$ for $15 \mathrm{~min}$, which resulted in $97 \%$ yield of $\mathbf{7 a}$.

To exploit the substrate scope and generality of the method, various (hetero)aromatic aldehydes 2 were examined. The obtained results are summarized in Table 6. Benzaldehyde (2a) underwent the reaction with ethyl acetoacetate (4) and urea (5) to obtain the corresponding dihydropyrimidinone $\mathbf{7 a}$ in $97 \%$ yield (Table 6 , entry 1). Benzaldehyde derivatives bearing electron-donating groups, such as $4-\mathrm{Me}(\mathbf{2 b}), 4-\mathrm{OMe}$ (2e), 3,4-dimethoxy (2f), 3-OH (2r), and 2-OH (2h), respective$1 \mathrm{y}$, at different positions on the ring reacted well with ethyl acetoacetate (4) and urea (5) to produce the products, $7 \mathbf{b}-\mathbf{f}$ in good isolated yields that ranged from $92-96 \%$ (Table 6 , entries 2-6). A benzaldehyde derivative with an electron-accepting nitro group (2l) at the para position on the ring showed a good reactivity with ethyl acetoacetate (4) and urea (5) to afford the product $7 \mathbf{g}$ in an excellent isolated yield (94\%, Table 6, entry 7). Halogen atoms at different positions on the ring of benzaldehyde derivatives (4-F: $\mathbf{2 m}, 4-\mathrm{Cl} ; \mathbf{2 n}$, and 3-Br: $2 \mathbf{s}$ ) underwent the reaction with ethyl acetoacetate $(\mathbf{4})$ and urea $(5)$ to form the corresponding products $(\mathbf{7 h}-\mathbf{j})$ in good isolated yields that ranged from 93-96\% (Table 6, entries 8-10). Heteroaromatic aldehydes, such as furan-2-aldehyde (2p) and thiophene-2-aldehyde (2q) showed a good reactivity, with good yields of $\mathbf{7 k}$ (90\%) and $7 \mathbf{l}(92 \%)$, respectively (Table 6, entries 11 and 12). From this study, it was concluded that the optimized reaction conditions are suitable for monosubstituted (both electron-rich and electron-deficient) and disubstituted benzaldehyde derivatives as well as heteroaromatic aldehydes. To expand the scope of this method, thiourea (6) was also investigated (Table 6, entries 13-17). Benzaldehyde (2a) reacted with ethyl acetoacetate (4) and thiourea (6) to give the product $\mathbf{7 m}$ in an excellent isolated yield (96\%, Table 6, entry 13). Benzaldehyde derivatives bearing electron-donating groups, such as $4-\mathrm{Me}(\mathbf{2 b})$ and 4-OMe (2c) exhibited a good reactivity with ethyl acetoacetate (4) and thiourea (6) to produce the products $7 \mathbf{n}(95 \%)$ and 7o (95\%) in excellent yields, respectively (Table 6, entries 14 and 15). Benzaldehyde with electron-withdrawing groups, such as $4-\mathrm{NO}_{2}(\mathbf{2 f})$ and $4-\mathrm{Cl}(\mathbf{2 i})$ at the para position reacted well with ethyl acetoacetate (4) and thiourea (6) to afford the corresponding products $\mathbf{7 p}$ and $\mathbf{7 q}$ in good isolated yields (94 and 95\%) (Table 6, entries 16 and 17). Most of the synthesized compounds are known and were identified easily by compari- 
Table 6: NDL-catalyzed synthesis of dihydropyrimidinone/-thione derivatives $7 .^{\mathrm{a}}$

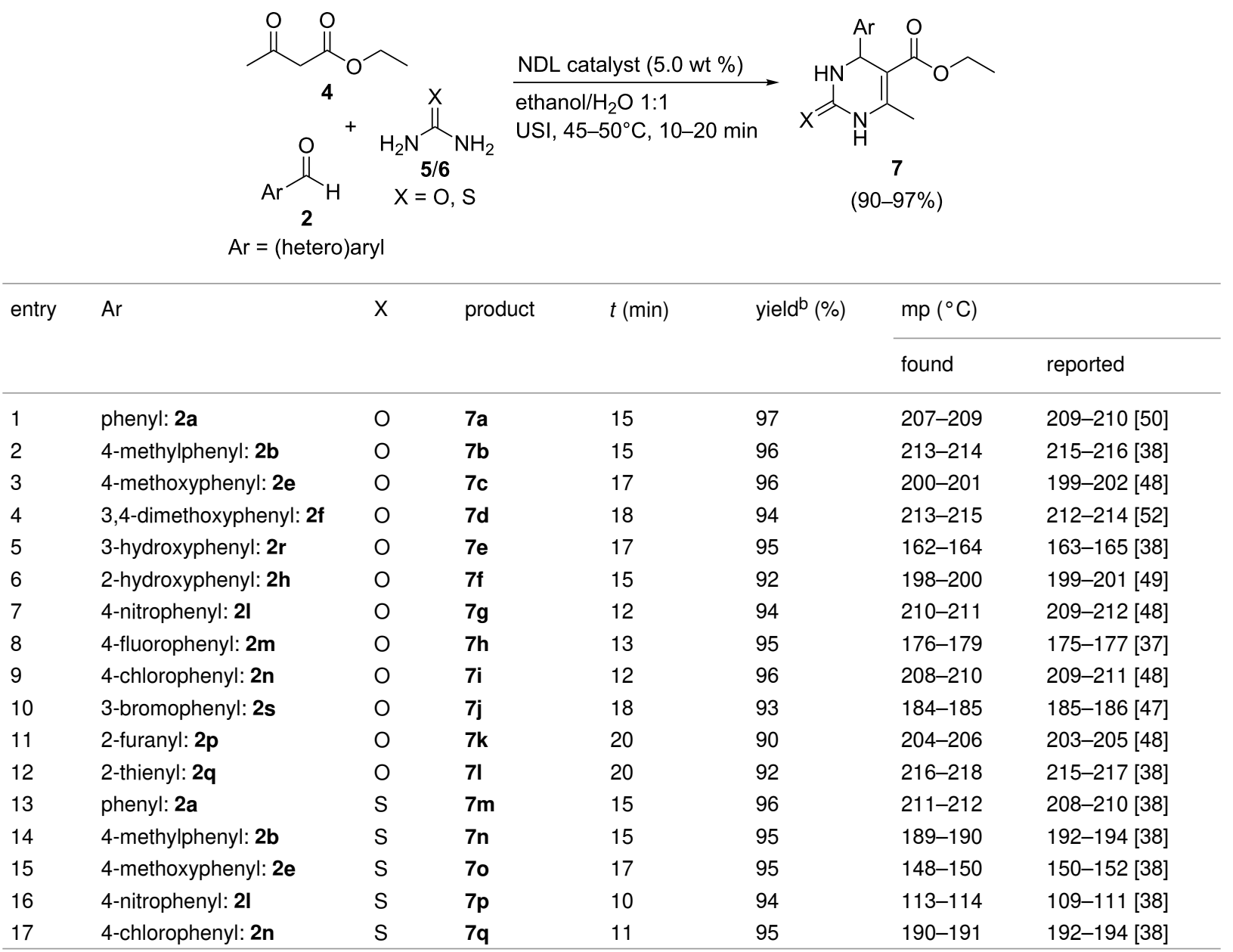

aReaction conditions: aldehyde $(2,1.0 \mathrm{mmol})$, ethyl acetoacetate $(4,1.0 \mathrm{mmol})$, urea/thiourea $(\mathbf{5} / \mathbf{6}, 1.0 \mathrm{mmol}), \mathrm{NDL}(5.0 \mathrm{wt} \%)$, ethanol/ $\mathrm{H}_{2} \mathrm{O} 1: 1$ $(3.0 \mathrm{~mL})$, USI at $45-50{ }^{\circ} \mathrm{C}$. bIsolated yield.

son of the melting point and spectroscopic data with those reported.

\section{NDL-catalyzed synthesis of 2-amino-4- (hetero)aryl-3,5-dicarbonitrile-6- sulfanylpyridines $\mathbf{1 1}$}

We further examined the catalytic efficacy of the NDL catalyst in the synthesis of the medicinally privileged highly functionalized pyridines 11. For this purpose, a control experiment in the absence of a catalyst was conducted by using the model substrates benzaldehyde (2a, $1.0 \mathrm{mmol})$, malononitrile $(\mathbf{8}$, $2.0 \mathrm{mmol})$, and 2-mercaptopyridine $(\mathbf{9}, 1.0 \mathrm{mmol})$ in $\mathrm{H}_{2} \mathrm{O}$ ( $3.0 \mathrm{~mL}$ ) under ultrasound irradiation at $45-50{ }^{\circ} \mathrm{C}$ for $60 \mathrm{~min}$. It was observed that the reaction did not afford any product in the absence of a catalyst. The above reaction was carried out in the presence of the NDL (5.0 wt \%) in EtOH/ $\mathrm{H}_{2} \mathrm{O} 1: 1(3.0 \mathrm{~mL})$ under ultrasound irradiation for $10 \mathrm{~min}$, which resulted in $70 \%$ yield of 11a. To improve the yield of 11a, the same reaction was repeated at different time intervals; $15,20,25,30,35$, and $40 \mathrm{~min}$, respectively, at $45-50{ }^{\circ} \mathrm{C}$, and the yields of $11 \mathrm{a}$ obtained were $75,83,89,96 \%, 96$, and $96 \%$, respectively. From this study, it was found that the maximum yield of 11a (96\%) was obtained in $30 \mathrm{~min}$, and the yields remained the same when the reaction time was increased from 30 to $40 \mathrm{~min}$.

The optimized procedure was successfully applied for the synthesis of a series of highly substituted pyridines $(\mathbf{1 1 b}-\mathbf{r}$, Table 7) by utilizing a range of (hetero)aromatic aldehydes $\mathbf{2}$, malononitrile (8), and the thiols $\mathbf{9}$ and 10, respectively, as starting materials. Benzaldehyde (2a) underwent the reaction with malononitrile (8) and 2-mercaptopyridine (9) to form product 11a in $96 \%$ yield (Table 7 , entry 1). Benzaldehyde deriva- 
Table 7: NDL-catalyzed synthesis of 2-amino-4-(hetero)aryl-3,5-dicarbonitrile-6-sulfanylpyridines 11. ${ }^{a}$

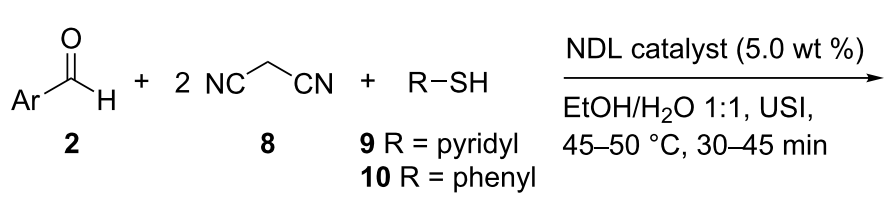<smiles>N#Cc1c(N)nc(SP)c(C#N)c1C#N</smiles>

$(90-98 \%)$

11

\begin{tabular}{|c|c|c|c|c|c|c|c|}
\hline \multirow[t]{2}{*}{ entry } & \multirow[t]{2}{*}{$\operatorname{Ar}$} & \multirow[t]{2}{*}{$\mathrm{R}$} & \multirow[t]{2}{*}{ product } & \multirow[t]{2}{*}{$t(\min )$} & \multirow[t]{2}{*}{ yield $(\%)$} & \multicolumn{2}{|l|}{$\mathrm{mp}\left({ }^{\circ} \mathrm{C}\right)$} \\
\hline & & & & & & found & reported \\
\hline 1 & phenyl: 2a & pyridyl 9 & $11 a$ & 30 & 96 & $222-223$ & 224-227 [70] \\
\hline 2 & 4-methoxyphenyl: $\mathbf{2 e}$ & pyridyl 9 & $11 b$ & 35 & 96 & $248-249$ & $250-253[70]$ \\
\hline 3 & 3,4,5-trimethoxyphenyl: $\mathbf{2 g}$ & pyridyl 9 & $11 c$ & 40 & 92 & $267-269$ & 265-268 [70] \\
\hline 4 & 3-hydroxyphenyl: $2 r$ & pyridyl 9 & $11 d$ & 35 & 94 & $223-224$ & $222-226[70]$ \\
\hline 5 & 4-nitrophenyl: 2I & pyridyl 9 & $11 \mathrm{e}$ & 32 & 96 & $241-243$ & 245-248 [70] \\
\hline 6 & 4-fluorophenyl: 2m & pyridyl: 9 & $11 f$ & 32 & 95 & $248-250$ & $246-249$ [70] \\
\hline 7 & 4-bromophenyl: 20 & pyridyl: 9 & $11 \mathrm{~g}$ & 30 & 94 & $257-258$ & $260-263$ [70] \\
\hline 8 & 3,4-difluorophenyl: $\mathbf{2 t}$ & pyridyl: 9 & $11 \mathrm{~h}$ & 37 & 90 & $252-253$ & $251-254[70]$ \\
\hline 9 & pyridyl: 2u & pyridyl: 9 & $11 \mathrm{i}$ & 45 & 93 & $230-231$ & $233-235[70]$ \\
\hline 10 & phenyl: 2a & phenyl: 10 & $11 \mathrm{j}$ & 30 & 98 & $210-212$ & $215-216$ [63] \\
\hline 11 & 4-methylphenyl: $\mathbf{2 b}$ & phenyl: 10 & $11 \mathrm{k}$ & 30 & 98 & $206-207$ & $208-210$ [69] \\
\hline 12 & 4-methoxyphenyl: $\mathbf{2 e}$ & phenyl: 10 & 111 & 35 & 97 & $234-235$ & $236-238[64]$ \\
\hline 13 & 3,4,5-trimethoxyphenyl: $\mathbf{2 g}$ & phenyl: 10 & $11 \mathrm{~m}$ & 38 & 94 & $240-241$ & 238-239 [63] \\
\hline 14 & 4-nitrophenyl: 2 I & phenyl: 10 & $11 n$ & 30 & 95 & $280-282$ & $286-287$ [63] \\
\hline 15 & 4-fluorophenyl: 2m & phenyl: $\mathbf{1 0}$ & 110 & 30 & 96 & $127-128$ & $224-225$ [69] \\
\hline 16 & 4-chlorophenyl: 2n & phenyl: 10 & $11 p$ & 30 & 96 & $220-221$ & 222-223 [69] \\
\hline 17 & 3-bromophenyl: 2s & phenyl: 10 & $11 q$ & 34 & 94 & $250-253$ & $256-258$ [65] \\
\hline 18 & pyridyl: $\mathbf{2 u}$ & phenyl: 10 & $11 \mathrm{r}$ & 42 & 94 & $300-302$ & $305-306[63]$ \\
\hline
\end{tabular}

aReaction conditions: aldehyde $(\mathbf{2}, 1.0 \mathrm{mmol})$, malononitrile $(\mathbf{8}, 2.0 \mathrm{mmol})$, thiol 9 or $10(1.0 \mathrm{mmol}), \mathrm{NDL}(5.0 \mathrm{wt} \%), \mathrm{EtOH} / \mathrm{H}_{2} \mathrm{O} 1: 1(3.0 \mathrm{~mL}), \mathrm{USI}$ at $45-50^{\circ} \mathrm{C}$. ${ }^{\mathrm{b}}$ Isolated yield.

tives containing a range of functional groups, such as electrondonating groups (4-OMe: $\mathbf{2 e}, 3,4,5$-trimethoxy: $\mathbf{2 g}$, and 3-OH: 2r), an electron-withdrawing group $\left(4-\mathrm{NO}_{2}: \mathbf{2 l}\right)$, and halogen atoms (4-F: 2m, 4-Cl: 2n, and 3,4-difluoro: $2 \mathbf{t}$ ), respectively, at different positions on the aromatic ring showed a good reactivity with the said reactants and afforded the corresponding products 11b-h that ranged from 90 to $96 \%$ (Table 7, entries 2-8). Further, the use of pyridine-2-aldehyde (2u) resulted in a good isolated yield of $\mathbf{1 1 i}$ (93\%, Table 7, entry 9). In a similar way, the reaction of benzaldehyde (2a) with malononitrile (8) and thiophenol (10) gave the product $\mathbf{1 1} \mathbf{j}$ in $98 \%$ yield (Table 7 , entry 10). Benzaldehyde derivatives bearing various functional groups, such as electron-donating groups (4-Me: $\mathbf{2 b}, 4-\mathrm{OMe}$ : $\mathbf{2 e}$, and 3,4,5-trimethoxy: 2g), an electron-accepting group $\left(4-\mathrm{NO}_{2}: \mathbf{2 l}\right)$, and halogen atoms (4-F: $\mathbf{2 m}, 4-\mathrm{Cl}: \mathbf{2 n}$, and 3-Br: 2s), respectively, at different positions on the aromatic ring displayed a good reactivity with malononitrile (8) and thiophenol $(\mathbf{1 0})$ to give the corresponding products $(\mathbf{1 1 k}-\mathbf{q})$ in good yields, ranging from 94 to $98 \%$ (Table 7, entries 11-17). Pyridine-2-aldehyde (2u) also provided the product $\mathbf{1 1 r}$ in a good yield (94\%, Table 7, entry 18). It was observed from the above results that all reactions proceeded well irrespective of the substituents present on the (hetero)aromatic aldehyde and afforded the highly substituted pyridines $\mathbf{1 1}$ in good isolated yields that ranged from 90 to $98 \%$. Most of the synthesized compounds are known and were identified easily by comparison of the melting point and spectroscopic data with those reported.

\section{Evaluation of the green chemistry metrics for the synthesis of benzimidazoles $\mathbf{3}$, dihydropyrimidinones 7 , and highly functionalized pyridines 11}

In order to evaluate the "greenness" of the proposed methodologies, the green chemistry metrics, such as the atom economy (AE), E-factor, process mass intensity (PMI), Curzon's reac- 
tion mass efficiency (RME), and generalized or global reaction mass efficiency (gRME) were evaluated by adopting established standard empirical formulae $[88,89]$. The obtained results are summarized in Tables $8-10$. This study revealed that the reactions displayed a good to excellent $\mathrm{AE}(88-95 \%)$ and Curzon's RME (78-93\%) as well as a low to moderate E-factor (26.202-50.760) and PMI (27.202-51.760). The detailed calculations of the green chemistry metrics (AE, E-factor, PMI, Curzon's RME, and gRME) for the synthesis of the compounds 3a, 7a, and 11a (Table 8, entry 1, Table 9, entry 1, and Table 10, entry 1) are presented in Supporting Information File 1 (see Reaction-S1-Reaction-S3).

\section{Catalyst reusability experiments}

Catalyst reusability tests were performed showcasing the synthesis of the compounds $\mathbf{3 k}, \mathbf{7} \mathbf{a}$, and $\mathbf{1 1 e}$ under the optimized reaction conditions.

\section{Catalyst reusability experiments in the synthesis of compounds $3 \mathrm{k}, \mathbf{7 a}$, and $\mathbf{1 1 e}$}

The catalyst was tested for reusability in the preparation of $\mathbf{3 k}$ using $o$-phenylenediamine (1) and 3-ethoxy-4-hydroxybenzaldehyde (2k) under USI for $10 \mathrm{~min}$. After completion of the first reaction cycle, the reaction mass was allowed to cool to rt, and ethyl acetate $(4.0 \mathrm{~mL})$ was added. Then, the catalyst was

Table 8: Green chemistry metrics for the synthesis of 2-aryl-1-arylmethyl-1H-benzo[d]imidazoles 3
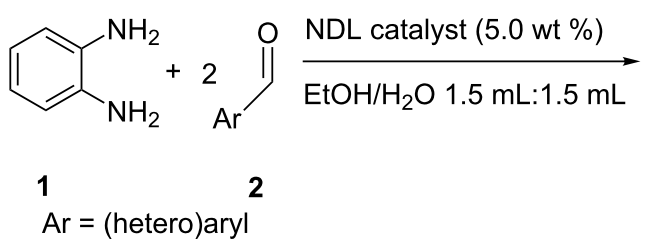

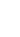
$(3 \mathbf{a}-\mathbf{g}$ and $\mathbf{3 j - q})$ $(94-98 \%)$

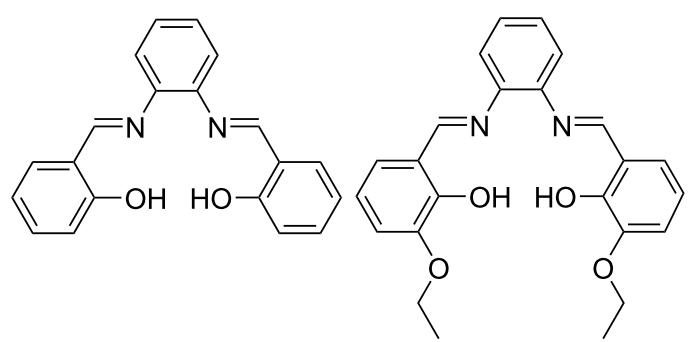

$3 \mathbf{h}$ $(98 \%)$
$3 \mathbf{i}$ $(96 \%)$

\begin{tabular}{|c|c|c|c|c|c|c|c|}
\hline entry & $\mathrm{Ar}$ & product & $\mathrm{AE}^{\mathrm{a}}(\%)$ & E-factor ${ }^{b}$ & PMIC & $\begin{array}{l}\text { Curzon's } \\
\text { RMEd } \\
(\%)\end{array}$ & $\begin{array}{l}\text { gRMEe } \\
(\%)\end{array}$ \\
\hline 1 & phenyl: 2a & $3 a$ & 89 & 40.864 & 41.864 & 87 & 2.4 \\
\hline 2 & 4-methylphenyl: 2b & $3 b$ & 90 & 37.261 & 38.261 & 88 & 2.6 \\
\hline 3 & 4-tert-butylphenyl: 2c & $3 c$ & 92 & 30.614 & 31.614 & 86 & 3.2 \\
\hline 4 & 2,4-dimethylphenyl: 2d & $3 d$ & 90 & 35.044 & 36.044 & 86 & 2.8 \\
\hline 5 & 4-methoxyphenyl: $\mathbf{2 e}$ & $3 e$ & 91 & 33.837 & 34.837 & 89 & 2.9 \\
\hline 6 & 3,4-dimethoxyphenyl: $\mathbf{2 f}$ & $3 f$ & 92 & 29.729 & 30.729 & 87 & 3.3 \\
\hline 7 & 3,4,5-trimethoxyphenyl: $\mathbf{2 g}$ & $3 g$ & 93 & 26.202 & 27.202 & 87 & 3.7 \\
\hline 8 & 2-hydroxyphenyl: $\mathbf{2 h}$ & $3 h$ & 90 & 36.781 & 37.781 & 88 & 2.6 \\
\hline 9 & 2-hydroxy-3-ethoxyphenyl: 2i & $3 \mathbf{i}$ & 92 & 29.412 & 30.412 & 88 & 3.3 \\
\hline 10 & 4-hydroxy-3-methoxyphenyl: 2j & $3 \mathbf{j}$ & 91 & 31.609 & 32.609 & 88 & 3.1 \\
\hline 11 & 4-hydroxy-3-ethoxyphenyl: 2k & $3 k$ & 92 & 29.102 & 30.102 & 89 & 3.3 \\
\hline 12 & 4-nitrophenyl: 2I & 31 & 91 & 31.017 & 32.017 & 89 & 3.1 \\
\hline 13 & 4-fluorophenyl: 2m & $3 m$ & 90 & 36.312 & 37.312 & 88 & 2.7 \\
\hline 14 & 4-chlorophenyl: 2n & $3 n$ & 91 & 33.052 & 34.052 & 89 & 2.9 \\
\hline 15 & 4-bromophenyl: 20 & 30 & 93 & 26.920 & 27.920 & 89 & 3.6 \\
\hline 16 & 2-furanyl: 2p & $3 p$ & 88 & 45.454 & 46.454 & 84 & 2.2 \\
\hline 17 & 2-thienyl: $\mathbf{2 q}$ & $3 q$ & 89 & 40.169 & 41.169 & 85 & 2.4 \\
\hline
\end{tabular}

${ }^{a} A E=100 \cdot\left(G M W\right.$ of the product/sum of the GMWs of the reactants); GMW = gram molecular weight. ${ }^{b} E$-factor $=$ total input mass $\left({ }^{m_{i n p u t s}}\right)^{f}-$ mass of the target product $\left({ }^{m_{3}}\right)-$ mass of the recovered materials $/{ }^{m_{3}}$. ${ }^{c P M I}=\left(m_{\text {inputs }}-\right.$ mass of the recovered materials $) / m_{3}$ or $1+E-f a c t o r$.

${ }^{\mathrm{d} C u r z o n ' s} \mathrm{RME}=\mathrm{m}_{\mathbf{3}} / \mathrm{m}_{\mathbf{1}}+\mathrm{m}_{\mathbf{2}}$ or yield $\times \mathrm{AE} \times 1$ /stoichiometric factor $(\mathrm{SF}) ; \mathrm{SF}=1 .{ }^{\mathrm{e}} \mathrm{gRME}=100 \cdot\left(\mathrm{m}_{\mathbf{3}} /\left(\mathrm{m}_{\mathrm{inp}}\right.\right.$ uts - mass of the recovered materials $\left.)\right)$ or

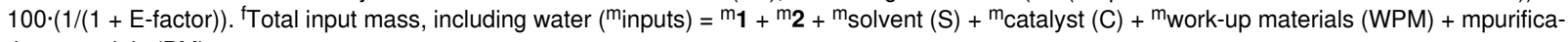
tion materials $(\mathrm{PM})$. 
Table 9: Green chemistry metrics for the synthesis of dihydropyrimidinones/-thiones 7.

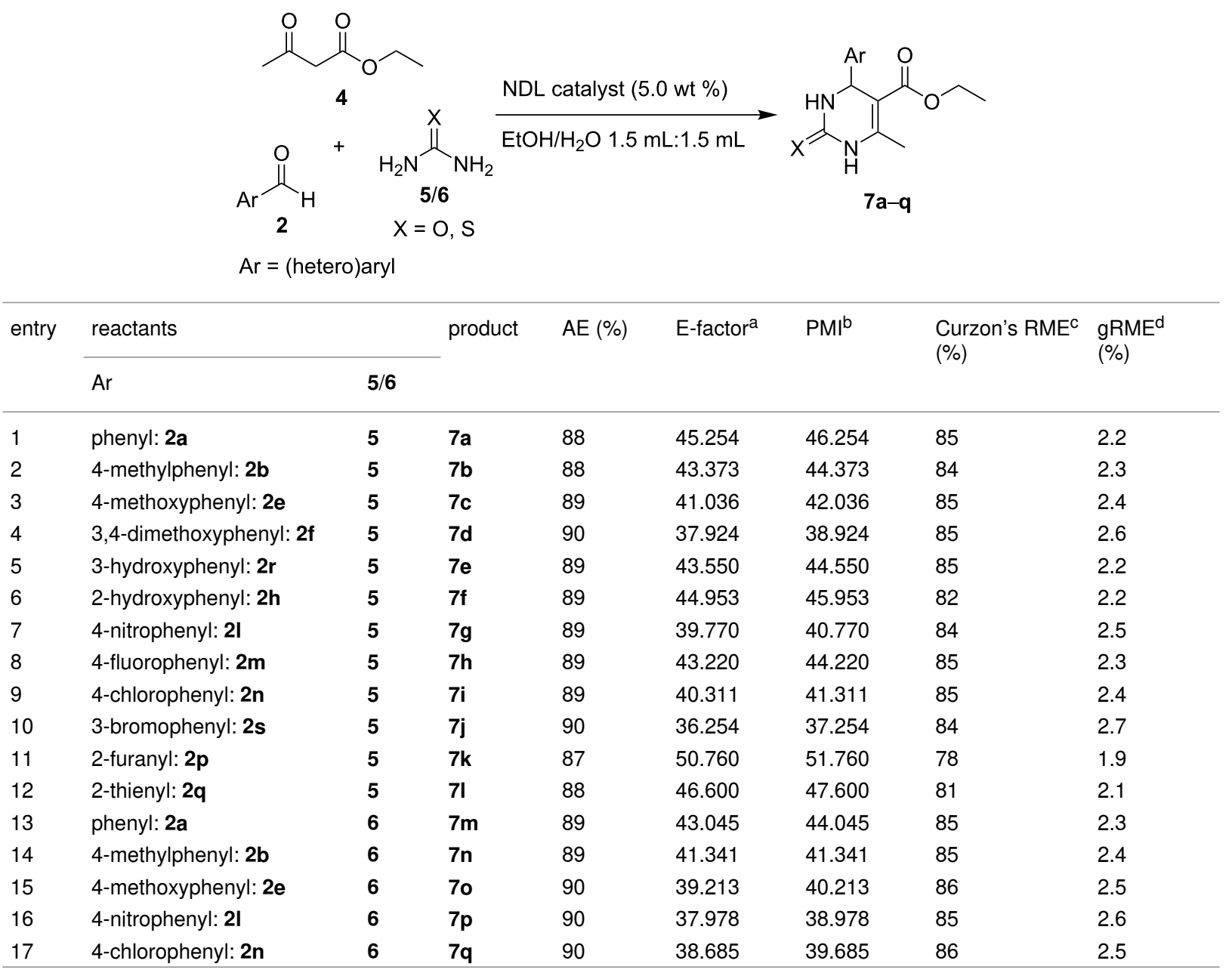

${ }^{a}$-factor $=m_{\text {inputs }}{ }^{\mathrm{e}}-$ mass of the target product $\left({ }^{m_{7}}\right)-$ mass of the recovered materials $/{ }^{\mathrm{m}} \mathbf{7}$. bPMI $=\left(\mathrm{m}_{\text {inputs }}-\right.$ mass of the recovered materials $) /{ }^{m_{7}}$ or $1+E$-factor. ${ }^{c}$ Curzon's RME $={ }^{m_{7}} /{ }^{m} \mathbf{2}+{ }^{m} \mathbf{4}+{ }^{m} \mathbf{5} / \mathbf{6}$ or yield $\times A E \times 1 / S F ; S F=1 .{ }^{d} g R M E=100 \cdot\left({ }^{7} \mathbf{7} /\left(m_{i n p u t s}-\right.\right.$ mass of the recovered materials $)$ ) or $100 \cdot(1 /(1+E$-factor $)) .{ }^{e m_{i n p u t s}}={ }^{m_{2}}+{ }^{m_{4}}+{ }^{m_{5 / 6}}+{ }^{m} S+{ }^{m} C+{ }^{m_{W P M}}+{ }^{m_{p}}$ purification materials (PM).

separated by vacuum filtration, washed with ethyl acetate $(1.0 \mathrm{~mL})$, dried under vacuum, and reused in the next cycles. The study revealed that the obtained yields of the product, $\mathbf{3 k}$ were $98,98,97,97,96,97$, and $98 \%$ for the first, second, third, fourth, fifth, sixth, and seventh cycle, respectively. Catalyst reusability tests were then conducted for the synthesis of compound 7a using benzaldehyde (2a), ethyl acetoacetate (4), and urea (5) under USI for $15 \mathrm{~min}$ and for 11e using 4-nitrobenzaldehyde (2l), malononitrile (8), and 2-mercaptopyridine (9) under USI for $32 \mathrm{~min}$ by following the same procedure as adopted for $\mathbf{3 k}$. The yields obtained for the compounds were 97 , $97,97,96,97,97$, and $97 \%$ for $7 \mathbf{a}$ as well as $96,96,96,97,97$, 97, and $98 \%$ for 11e for the first, second, third, fourth, fifth, sixth, and seventh cycle, respectively. From this study, it was noticed that the catalyst could successfully be reused (at least) 7 times in the synthesis of the compounds $3 \mathbf{k}, \mathbf{7 a}$, and $11 \mathbf{e}$ without a significant loss of the catalytic activity.

\section{Effect of ultrasonication on the structure of the catalyst}

The recovered catalyst after the 7th cycle of each synthesis was characterized by XRD to study the structural changes due to ultrasonication. As can be seen in Figure 8, the diffraction peak positions of the catalyst recovered after the synthesis of the compounds $3 \mathbf{k}, 7 \mathbf{a}$, and 11e (Figure 8b-d), respectively, remained the same as compared to the fresh catalyst (Figure 8a). It was also noticed that the broadening in the XRD pattern of the recovered catalyst had increased with an increase 
Table 10: Green chemistry metrics for the synthesis of 2-amino-4-(hetero)aryl-3,5-dicarbonitrile-6-sulfanylpyridines 11.

$$
\begin{aligned}
& 2 \mathrm{NC} \widehat{C N}
\end{aligned}
$$

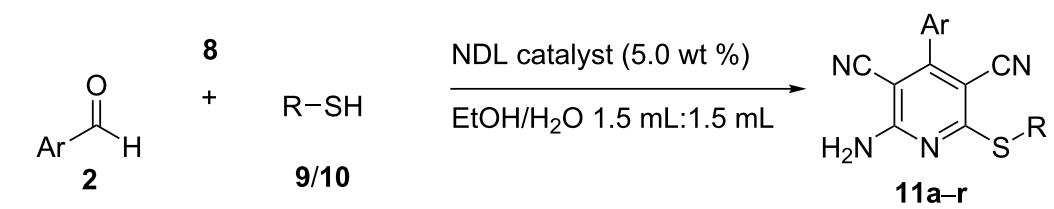

$$
\begin{aligned}
& \mathrm{Ar}=\text { (hetero)aryl } 9 \mathrm{R}=\text { pyridyl } \\
& 10 \mathrm{R}=\text { phenyl }
\end{aligned}
$$

\begin{tabular}{|c|c|c|c|c|c|c|c|c|}
\hline \multirow[t]{2}{*}{ entry } & \multicolumn{2}{|l|}{ reactants } & \multirow[t]{2}{*}{ product } & \multirow[t]{2}{*}{$A E(\%)$} & \multirow[t]{2}{*}{ E-factora } & \multirow[t]{2}{*}{ PMI ${ }^{b}$} & \multirow{2}{*}{$\begin{array}{l}\text { Curzon's } \\
\text { RMEC }^{\circ} \\
(\%)\end{array}$} & \multirow{2}{*}{$\begin{array}{l}\text { gRMEd } \\
(\%)\end{array}$} \\
\hline & $\mathrm{Ar}$ & $\mathrm{R}$ & & & & & & \\
\hline 1 & phenyl: 2a & pyridyl: 9 & $11 a$ & 94 & 36.054 & 37.054 & 90 & 2.7 \\
\hline 2 & 4-methoxyphenyl: $2 e$ & pyridyl: 9 & $11 b$ & 95 & 33.026 . & 34.026 & 91 & 2.9 \\
\hline 3 & 3,4,5-trimethoxyphenyl: $\mathbf{2 g}$ & pyridyl: 9 & $11 \mathrm{c}$ & 95 & 29.647 & 30.647 & 87 & 3.3 \\
\hline 4 & 3-hydroxyphenyl: $2 r$ & pyridyl: 9 & $11 d$ & 95 & 35.188 & 36.188 & 89 & 2.8 \\
\hline 5 & 4-nitrophenyl: 2l & pyridyl: 9 & $11 e$ & 95 & 31.741 & 32.741 & 91 & 3.1 \\
\hline 6 & 4-fluorophenyl: 2m & pyridyl: 9 & $11 f$ & 95 & 34.356 & 35.356 & 90 & 2.8 \\
\hline 7 & 4-bromophenyl: 20 & pyridyl: 9 & $11 \mathrm{~g}$ & 95 & 29.698 & 30.698 & 89 & 3.3 \\
\hline 8 & 3,4-difluorophenyl: $\mathbf{2 t}$ & pyridyl: 9 & $11 \mathrm{~h}$ & 95 & 34.699 & 35.699 & 86 & 2.8 \\
\hline 9 & pyridyl: 2u & pyridyl: 9 & $11 i$ & 94 & 37.143 & 38.143 & 87 & 2.6 \\
\hline 10 & Phenyl: 2a & phenyl: 10 & $11 \mathrm{j}$ & 94 & 35.474 & 36.474 & 92 & 2.7 \\
\hline 11 & 4-methylphenyl: 2b & phenyl: 10 & $11 k$ & 95 & 33.991 & 34.991 & 93 & 2.9 \\
\hline 12 & 4-methoxyphenyl: $2 e$ & phenyl: 10 & 111 & 95 & 32.827 & 33.827 & 92 & 3.0 \\
\hline 13 & 3,4,5-trimethoxyphenyl: $\mathbf{2 g}$ & phenyl: 10 & $11 \mathrm{~m}$ & 95 & 29.020 & 30.020 & 89 & 3.3 \\
\hline 14 & 4-nitrophenyl: 2l & phenyl: 10 & $11 n$ & 95 & 32.021 & 33.021 & 90 & 3.0 \\
\hline 15 & 4-fluorophenyl: 2m & phenyl: 10 & 110 & 95 & 34.319 & 35.319 & 91 & 2.8 \\
\hline 16 & 4-chlorophenyl: 2n & phenyl: 10 & $11 p$ & 95 & 32.744 & 33.744 & 91 & 3.0 \\
\hline 17 & 3-bromophenyl: 2s & phenyl: 10 & $11 q$ & 95 & 29.775 & 30.775 & 89 & 3.2 \\
\hline 18 & pyridyl: 2u & phenyl: 10 & $11 r$ & 94 & 36.893 & 37.893 & 88 & 2.6 \\
\hline
\end{tabular}

${ }^{a}$ E-factor $=m_{\text {inputs }}{ }^{\prime}-$ mass of the target product $\left({ }^{m_{11}}\right)-$ mass of the recovered materials $/{ }^{m} \mathbf{1 1}$. ${ }^{b} P M I=\left(m_{\text {inputs }}-\right.$ mass of the recovered materials $) /$

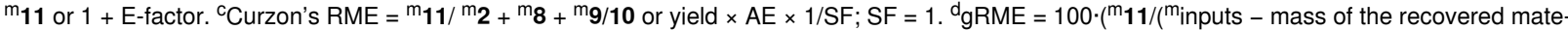
rials $)$ ) or $100 \cdot(1 /(1+E$-factor $))$. eminputs $=m_{2}+m_{\mathbf{8}}+{ }^{m} \mathbf{g} / 10+{ }^{m} S+{ }^{m} C+{ }^{m} W P M+{ }^{m P M}$.

of the ultrasonication time. This clearly indicated that the amorphization of the recovered catalyst was enhanced by increasing the ultrasonication time.

\section{Conclusion}

An environmentally benign NDL catalyst was characterized and utilized as a heterogeneous catalyst for the synthesis of 2-aryl1-arylmethyl-1 $H$-benzo $[d]$ imidazoles, dihydropyrimidinones/ -thiones, and 2-amino-4-(hetero)aryl-3,5-dicarbonitrile-6sulfanylpyridines in a mixture of ethanol and $\mathrm{H}_{2} \mathrm{O} 1: 1$ under ultrasound irradiation. Notable advantages of this methodology include the clean reaction profile, broad substrate scope, simplicity of the process and handling, low catalyst loading, and the easy and quick isolation of the products in good to excellent yield. Besides, the products obtained were in an adequate purity without the need for chromatographic separation, and the catalyst was reused 7 times without a significant loss of the catalytic activity. Hence, the catalyst is a greener alternative for the synthesis of 1,2-disubstituted benzimidazoles, dihydropyrimidinones/-thiones, and highly substituted pyridines when compared to the existing reported catalysts. Further, the expansion of the catalyst scope and the generality for the synthesis of other privileged nitrogen- and sulfur-based heterocycles is under progress in our laboratory.

\section{Experimental}

See Supporting Information File 1 for full experimental data of compounds $\mathbf{3}, \mathbf{7}$, and $\mathbf{1 1}$. 


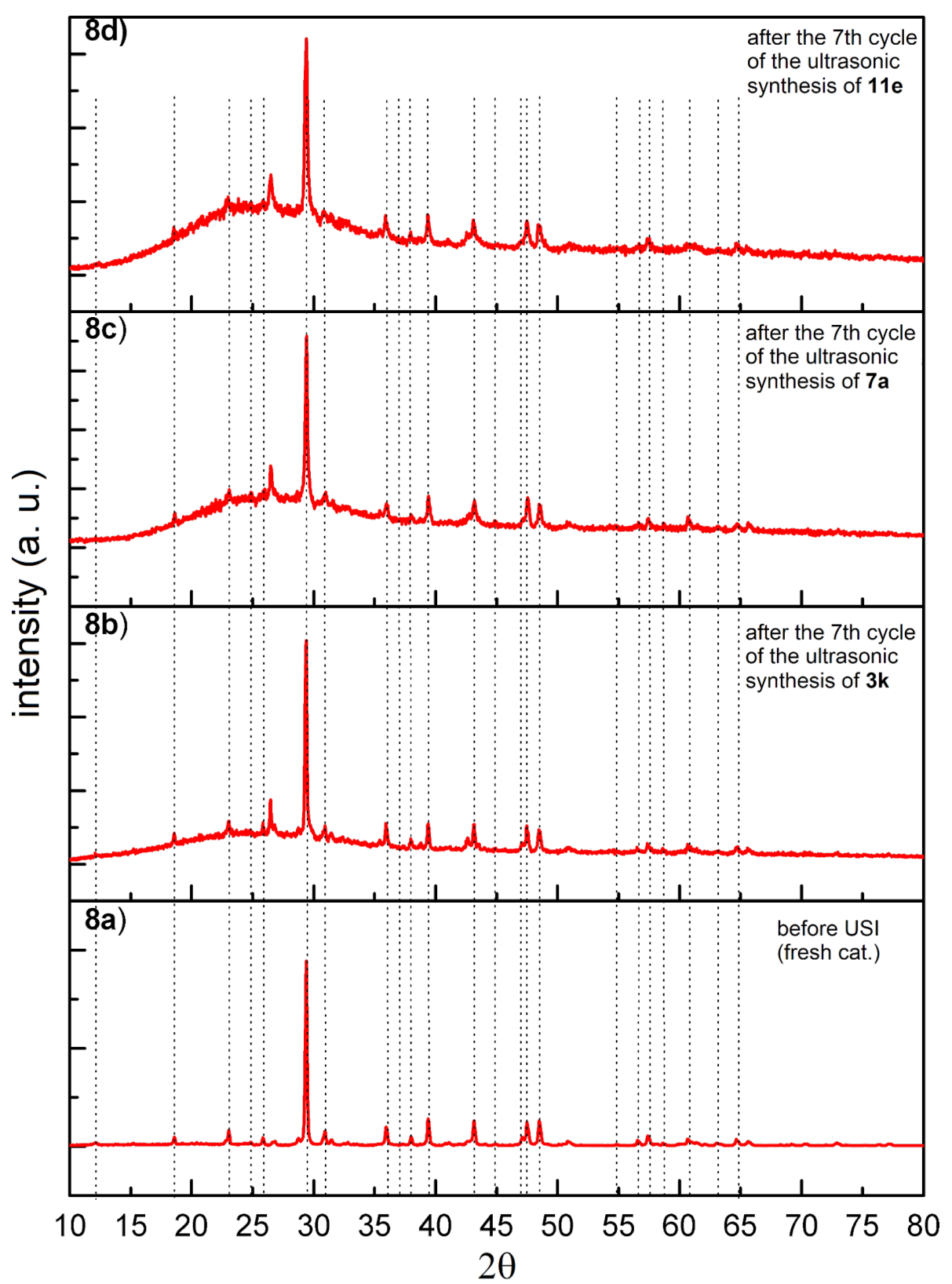

Figure 8: XRD pattern of a) the fresh NDL catalyst; b) the recovered NDL catalyst after the 7th cycle of the ultrasonic synthesis of $\mathbf{3 k}$; c) the recovered NDL catalyst after the 7th cycle of the ultrasonic synthesis of $7 \mathbf{a}$; and d) the recovered NDL catalyst after the 7th cycle of the ultrasonic synthesis of 11e.

\section{Supporting Information}

\section{Supporting Information File 1}

Experimental procedures, characterization data, and copies of the ${ }^{1} \mathrm{H}$ and ${ }^{13} \mathrm{C}$ NMR, mass, and HRMS spectra of $\mathbf{3}, \mathbf{7}$, and 11.

[https://www.beilstein-journals.org/bjoc/content/ supplementary/1860-5397-16-156-S1.pdf]

\section{Acknowledgements}

The authors thank Dr. R. V. J. Kashyap, Dept. of English, Yogi Vemana University, for critical reading of the manuscript to ensure linguistic correctness.

\section{Funding}

The authors gratefully acknowledge the financial support for this work from the Department of Atomic Energy Board of Research in Nuclear Sciences (Bhabha Atomic Research Centre), Mumbai, Government of India, through a major 
research project (No. 2011/37C/52/BRNS/2264) and the Council of Scientific and Industrial Research (CSIR), New Delhi, Government of India, under a major research project (No. 01 (2391)/10/EMR-II).

\section{ORCID ${ }^{\circledR}$ iDs}

Lakshmi Reddy Sanapareddy - https://orcid.org/0000-0001-9475-5516 Chinna Gangi Reddy Nallagondu - https://orcid.org/0000-0003-2088-802X

\section{Preprint}

A non-peer-reviewed version of this article has been previously published as a preprint doi:10.3762/bxiv.2020.39.v1

\section{References}

1. Joule, J. A.; Mills, K. Heterocyclic Chemistry, 4th ed.; Blackwell: Oxford, U.K., 2000.

2. Katritzky, A. R.; Ramsden, C. A.; Scriven, E. F. V.; Taylor, R. J. K., Eds. Comprehensive Heterocyclic Chemistry III; Elsevier: Oxford, U.K., 2008; Vol. 7.

3. Bull, J. A.; Mousseau, J. J.; Pelletier, G.; Charette, A. B. Chem. Rev. 2012, 112, 2642-2713. doi:10.1021/cr200251d And references therein.

4. Nagarajaiah, H.; Mukhopadhyay, A.; Moorthy, J. N. Tetrahedron Lett. 2016, 57, 5135-5149. doi:10.1016/j.tetlet.2016.09.047

5. Suresh; Sandhu, J. S. ARKIVOC 2012, No. i, 66-133. doi:10.3998/ark.5550190.0013.103

6. Perrier, V.; Wallace, A. C.; Kaneko, K.; Safar, J.; Prusiner, S. B.; Cohen, F. E. Proc. Natl. Acad. Sci. U. S. A. 2000, 97, 6073-6078. doi:10.1073/pnas.97.11.6073

7. Fredholm, B. B.; Ijzerman, A. P.; Jacobson, K. A.; Klotz, K.-N.; Linden, J. Pharmacol. Rev. 2001, 53, 527-552.

8. Nguyen, T. B.; Ermolenko, L.; Al-Mourabit, A. J. Am. Chem. Soc. 2013, 135, 118-121. doi:10.1021/ja311780a

9. Vitaku, E.; Smith, D. T.; Njardarson, J. T. J. Med. Chem. 2014, 57, 10257-10274. doi:10.1021/jm501100b

10. Preston, P. N. Chem. Rev. 1974, 74, 279-314. doi:10.1021/cr60289a001

11. Scott, L. J.; Dunn, C. J.; Mallarkey, G.; Sharpe, M. Drugs 2002, 62, 1503-1538. doi:10.2165/00003495-200262100-00006

12. Carcanague, D.; Shue, Y.-K.; Wuonola, M. A.; Uria-Nickelsen, M.; Joubran, C.; Abedi, J. K.; Jones, J.; Kühler, T. C. J. Med. Chem. 2002, 45, 4300-4309. doi:10.1021/jm020868v

13. Boiani, M.; Gonzalez, M. Mini-Rev. Med. Chem. 2005, 5, 409-424. doi:10.2174/1389557053544047 And references therein.

14. Shah, D. I.; Sharma, M.; Bansal, Y.; Bansal, G.; Singh, M. Eur. J. Med. Chem. 2008, 43, 1808-1812. doi:10.1016/j.ejmech.2007.11.008

15. Zhu, G.-D.; Gandhi, V. B.; Gong, J.; Thomas, S.; Luo, Y.; Liu, X.; Shi, Y.; Klinghofer, V.; Johnson, E. F.; Frost, D.; Donawho, C.; Jarvis, K.; Bouska, J.; Marsh, K. C.; Rosenberg, S. H.; Giranda, V. L.; Penning, T. D. Bioorg. Med. Chem. Lett. 2008, 18, 3955-3958. doi:10.1016/j.bmcl.2008.06.023

16. Ogino, Y.; Ohtake, N.; Nagae, Y.; Matsuda, K.; Moriya, M.; Suga, T.; Ishikawa, M.; Kanesaka, M.; Mitobe, Y.; Ito, J.; Kanno, T.; Ishihara, A.; Iwaasa, H.; Ohe, T.; Kanatani, A.; Fukami, T. Bioorg. Med. Chem. Lett. 2008, 18, 5010-5014. doi:10.1016/j.bmcl.2008.08.018
17. Molander, G. A.; Ajayi, K. Org. Lett. 2012, 14, 4242-4245. doi:10.1021/ol301956p

18. Asensio, J. A.; Gómez-Romero, P. Fuel Cells 2005, 5, 336-343. doi:10.1002/fuce.200400081

19. Schwartz, G.; Fehse, K.; Pfeiffer, M.; Walzer, K.; Leo, K. Appl. Phys. Lett. 2006, 89, 083509. doi:10.1063/1.2338588

20. Mariappan, G.; Hazarika, R.; Alam, F.; Karki, R.; Patangia, U.; Nath, S. Arabian J. Chem. 2015, 8, 715-719. doi:10.1016/j.arabjc.2011.11.008 And referenes therein.

21. Salahuddin; Shaharyar, M.; Mazumder, A.; Ahsan, M. J. Arabian J. Chem. 2014, 7, 418-424. doi:10.1016/j.arabjc.2013.02.001 And references therein

22. Ravi, V.; Ramu, E.; Vijay, K.; Srinivas Rao, A. Chem. Pharm. Bull. 2007, 55, 1254-1257. doi:10.1248/cpb.55.1254

23. Wan, J.-P.; Gan, S.-F.; Wu, J.-M.; Pan, Y. Green Chem. 2009, 11, 1633-1637. doi:10.1039/b914286j

24. Sharma, S. D.; Konwar, D. Synth. Commun. 2009, 39, 980-991. doi:10.1080/00397910802448440

25. Reddy, L. S.; Reddy, N. C. G.; Reddy, T. R.; Lingappa, Y.; Mohan, R. B. J. Korean Chem. Soc. 2011, 55, 304-307. doi:10.5012/jkcs.2011.55.2.304

26. Chebolu, R.; Kommi, D. N.; Kumar, D.; Bollineni, N.; Chakraborti, A. K. J. Org. Chem. 2012, 77, 10158-10167. doi:10.1021/jo301793z

27. Zhang, L.-J.; Xia, J.; Zhou, Y.-Q.; Wang, H.; Wang, S.-W. Synth. Commun. 2012, 42, 328-336. doi:10.1080/00397911.2010.524337 And references therein.

28. Kumar, D.; Kommi, D. N.; Chebolu, R.; Garg, S. K.; Kumar, R.; Chakraborti, A. K. RSC Adv. 2013, 3, 91-98. doi:10.1039/c2ra21994h

29. Senthilkumar, S.; Kumarraja, M. Tetrahedron Lett. 2014, 55, 1971-1974. doi:10.1016/j.tetlet.2014.01.140 And references therein.

30. Herrera Cano, N.; Uranga, J. G.; Nardi, M.; Procopio, A.; Wunderlin, D. A.; Santiago, A. N. Beilstein J. Org. Chem. 2016, 12, 2410-2419. doi:10.3762/bjoc.12.235 And references therein.

31. Costanzo, P.; Nardi, M.; Oliverio, M. Eur. J. Org. Chem. 2020, 3954-3964. doi:10.1002/ejoc.201901923 And references therein.

32. Berlinck, R. G. S.; Burtoloso, A. C. B.; Kossuga, M. H. Nat. Prod. Rep. 2008, 25, 919-954. doi:10.1039/b507874c

33. Hu, E. H.; Sidler, D. R.; Dolling, U.-H. J. Org. Chem. 1998, 63, 3454-3457. doi:10.1021/jo970846u

34. Sakata, K.-I.; Someya, M.; Matsumoto, Y.; Tauchi, H.; Kai, M.; Toyota, M.; Takagi, M.; Hareyama, M.; Fukushima, M. Cancer Sci. 2011, 102, 1712-1716. doi:10.1111/j.1349-7006.2011.02004.x

35. Ramesh, B.; Bhalgat, C. M. Eur. J. Med. Chem. 2011, 46, 1882-1891. doi:10.1016/j.ejmech.2011.02.052

36. Kaira, K.; Serizawa, M.; Koh, Y.; Miura, S.; Kaira, R.; Abe, M.; Nakagawa, K.; Ohde, Y.; Okumura, T.; Murakami, H.; Tsuya, A.; Nakamura, Y.; Naito, T.; Takahashi, T.; Kondo, H.; Nakajima, T.; Endo, M.; Yamamoto, N. Lung Cancer 2011, 74, 419-425. doi:10.1016/j.lungcan.2011.04.001

37. Schroeder, P. E.; Hasinoff, B. B. Drug Metab. Dispos. 2005, 33, 1367-1372. doi:10.1124/dmd.105.005546

38. Ma, Y.; Qian, C.; Wang, L.; Yang, M. J. Org. Chem. 2000, 65, 3864-3868. doi:10.1021/jo9919052

39. Fu, N.-Y.; Yuan, Y.-F.; Cao, Z.; Wang, S.-W.; Wang, J.-T.; Peppe, C. Tetrahedron 2002, 58, 4801-4807. doi:10.1016/s0040-4020(02)00455-6 
40. Rodríguez-Domínguez, J. C.; Bernardi, D.; Kirsch, G. Tetrahedron Lett. 2007, 48, 5777-5780. doi:10.1016/j.tetlet.2007.06.104

41. Ahmed, N.; van Lier, J. E. Tetrahedron Lett. 2007, 48, 5407-5409. doi:10.1016/j.tetlet.2007.06.005

42. Chen, X.-H.; Xu, X.-Y.; Liu, H.; Cun, L.-F.; Gong, L.-Z. J. Am. Chem. Soc. 2006, 128, 14802-14803. doi:10.1021/ja065267y

43. Ryabukhin, S. V.; Plaskon, A. S.; Ostapchuk, E. N.; Volochnyuk, D. M.; Shishkin, O. V.; Shivanyuk, A. N.; Tolmachev, A. A. Org. Lett. 2007, 9, 4215-4218. doi:10.1021/ol701782v

44. Li, N.; Chen, X.-H.; Song, J.; Luo, S.-W.; Fan, W.; Gong, L.-Z. J. Am. Chem. Soc. 2009, 131, 15301-15310. doi:10.1021/ja905320q

45. Guggilapu, S. D.; Prajapati, S. K.; Nagarsenkar, A.; Lalita, G.; Vegi, G. M. N.; Babu, B. N. New J. Chem. 2016, 40, 838-843. doi:10.1039/c5nj02444g And references therein.

46. Barbero, M.; Cadamuro, S.; Dughera, S. Green Chem. 2017, 19, 1529-1535. doi:10.1039/c6gc03274e And references therein.

47. Oliverio, M.; Costanzo, P.; Nardi, M.; Rivalta, I.; Procopio, A. ACS Sustainable Chem. Eng. 2014, 2, 1228-1233. doi:10.1021/sc5000682

48. Ranu, B. C.; Hajra, A.; Jana, U. J. Org. Chem. 2000, 65, 6270-6272. doi:10.1021/jo000711f

49. Lu, J.; Bai, Y. Synthesis 2002, 466-470. doi:10.1055/s-2002-20956

50. Gangadasu, B.; Palaniappan, S.; Rao, V. J. Synlett 2004, 1285-1287. doi:10.1055/s-2004-822925

51. Russowsky, D.; Lopes, F. A.; da Silva, V. S. S.; Canto, K. F. S.; Montes D'Oca, M. G.; Godoi, M. N. J. Braz. Chem. Soc. 2004, 15, 165-169. doi:10.1590/s0103-50532004000200002

52. Tu, S.; Fang, F.; Zhu, S.; Li, T.; Zhang, X.; Zhuang, Q. Synlett 2004, 537-539. doi:10.1055/s-2004-815419

53. Fazaeli, R.; Tangestaninejad, S.; Aliyan, H.; Moghadam, M. Appl. Catal., A 2006, 309, 44-51. doi:10.1016/j.apcata.2006.04.043

54. Ahmed, B.; Khan, R. A.; Habibullah; Keshari, M. Tetrahedron Lett. 2009, 50, 2889-2892. doi:10.1016/j.tetlet.2009.03.177

55. Phukan, M.; Kalita, M. K.; Borah, R. Green Chem. Lett. Rev. 2010, 3 , 329-334. doi:10.1080/17518253.2010.487841

56. Zhang, X.; Gu, X.; Gao, Y.; Nie, S.; Lu, H. Appl. Organomet. Chem. 2017, 31, e3590. doi:10.1002/aoc.3590 And references therein.

57. Chitra, S.; Pandiarajan, K. Tetrahedron Lett. 2009, 50, 2222-2224. doi:10.1016/j.tetlet.2009.02.162

58. Han, B.; Han, R.-F.; Ren, Y.-W.; Duan, X.-Y.; Xu, Y.-C.; Zhang, W. Tetrahedron 2011, 67, 5615-5620. doi:10.1016/j.tet.2011.05.105

59. Shen, Z.-L.; Xu, X.-P.; Ji, S.-J. J. Org. Chem. 2010, 75, 1162-1167. doi:10.1021/jo902394y

60. Sheik Mansoor, S.; Syed Shafi, S.; Zaheer Ahmed, S. Arabian J. Chem. 2016, 9, S846-S851. doi:10.1016/j.arabjc.2011.09.018

61. Pandey, J.; Anand, N.; Tripathi, R. P. Tetrahedron 2009, 65, 9350-9356. doi:10.1016/j.tet.2009.09.002

62. Cocco, M. T.; Congiu, C.; Lilliu, V.; Onnis, V. Eur. J. Med. Chem. 2005, 40, 1365-1372. doi:10.1016/j.ejmech.2005.07.005

63. May, B. C. H.; Zorn, J. A.; Witkop, J.; Sherrill, J.; Wallace, A. C.; Legname, G.; Prusiner, S. B.; Cohen, F. E. J. Med. Chem. 2007, 50, 65-73. doi:10.1021/jm061045z

64. Reddy, T. R. K.; Mutter, R.; Heal, W.; Guo, K.; Gillet, V. J.; Pratt, S.; Chen, B. J. Med. Chem. 2006, 49, 607-615. doi:10.1021/jm050610f

65. Evdokimov, N. M.; Magedov, I. V.; Kireev, A. S.; Kornienko, A. Org. Lett. 2006, 8, 899-902. doi:10.1021/ol052994+
66. Evdokimov, N. M.; Kireev, A. S.; Yakovenko, A. A.; Antipin, M. Y.; Magedov, I. V.; Kornienko, A. J. Org. Chem. 2007, 72, 3443-3453. doi:10.1021/jo070114u

67. Ranu, B. C.; Jana, R.; Sowmiah, S. J. Org. Chem. 2007, 72, 3152-3154. doi:10.1021/jo070015g

68. Mamgain, R.; Singh, R.; Rawat, D. S. J. Heterocycl. Chem. 2009, 46, 69-73. doi:10.1002/jhet.32

69. Guo, K.; Thompson, M. J.; Chen, B. J. Org. Chem. 2009, 74, 6999-7006. doi:10.1021/jo901232b

70. Banerjee, S.; Sereda, G. Tetrahedron Lett. 2009, 50, 6959-6962. doi:10.1016/j.tetlet.2009.09.137

71. Shinde, P. V.; Sonar, S. S.; Shingate, B. B.; Shingare, M. S. Tetrahedron Lett. 2010, 51, 1309-1312. doi:10.1016/j.tetlet.2009.12.146

72. Srinivasula Reddy, L.; Ram Reddy, T.; Mohan, R. B.; Mahesh, A.; Lingappa, Y.; Gangi Reddy, N. C. Chem. Pharm. Bull. 2013, 61, 1114-1120. doi:10.1248/cpb.c13-00412

73. Tamaddon, F.; Tayefi, M.; Hosseini, E.; Zare, E. J. Mol. Catal. A: Chem. 2013, 366, 36-42. doi:10.1016/j.molcata.2012.08.027

74. Correia, L. M.; de Sousa Campelo, N.; Novaes, D. S.; Cavalcante, C. L., Jr.; Cecilia, J. A.; Rodríguez-Castellón, E.; Vieira, R. S. Chem. Eng. J. 2015, 269, 35-43. doi:10.1016/j.cej.2015.01.097

75. Vogel, A. I. Quantitative inorganic analysis; Longmans: London, U.K., $1951 ;$ p 582.

76. Gunasekaran, S.; Anbalagan, G.; Pandi, S. J. Raman Spectrosc. 2006, 37, 892-899. doi:10.1002/jrs.1518

77. Xu, B.; Poduska, K. M. Phys. Chem. Chem. Phys. 2014, 16, 17634-17639. doi:10.1039/c4cp01772b

78. Shawky, A.; El-Sheikh, S. M.; Rashed, M. N.; Abdo, S. M.; El-Dosoqy, T. I. J. Environ. Chem. Eng. 2019, 7, 103174. doi:10.1016/j.jece.2019.103174

79. Darezereshki, E.; Ranjbar, M.; Bakhtiari, F. J. Alloys Compd. 2010, 502, 257-260. doi:10.1016/j.jallcom.2010.04.163

80.Shao, M.; Ning, F.; Zhao, J.; Wei, M.; Evans, D. G.; Duan, X. J. Am. Chem. Soc. 2012, 134, 1071-1077. doi:10.1021/ja2086323

81. White, W. B.; Karr, C., Jr., Eds. Infrared and Raman Spectroscopy of Lunar and Terrestrial Minerals; Academic Press: New York, NY, USA, 1975.

82. Ramasesha, K.; De Marco, L.; Mandal, A.; Tokmakoff, A. Nat. Chem. 2013, 5, 935-940. doi:10.1038/nchem.1757

83. Shalaby, N. H.; Elsalamony, R. A.; El Naggar, A. M. A. New J. Chem. 2018, 42, 9177-9186. doi:10.1039/c8nj01479e

84. Lin, Y.-F.; Chen, H.-W.; Chang, C.-C.; Hung, W.-C.; Chiou, C.-S. J. Chem. Technol. Biotechnol. 2011, 86, 1449-1456. doi:10.1002/jctb.2665

85. Yadav, A. K.; Singh, P. RSC Adv. 2015, 5, 67583-67609. doi:10.1039/c5ra13043c And references therein.

86. Debure, M.; Andreazza, P.; Canizarès, A.; Grangeon, S.; Lerouge, C.; Mack, P.; Madé, B.; Simon, P.; Veron, E.; Warmont, F.; Vayer, M. ACS Earth Space Chem. 2017, 1, 442-454. doi:10.1021/acsearthspacechem.7b00073

87. Makal, A.; Schilf, W.; Kamieński, B.; Szady-Chelmieniecka, A.; Grech, E.; Woźniak, K. Dalton Trans. 2011, 40, 421-430. doi:10.1039/c0dt00298d

88. Andraos, J.; Hent, A. J. Chem. Educ. 2015, 92, 1820-1830. doi:10.1021/acs.jchemed.5b00058 
89. Dicks, A. P.; Hent, A. Green Chemistry Metrics; Springer International Publishing: Cham, Switzerland, 2015. doi:10.1007/978-3-319-10500-0

\section{License and Terms}

This is an Open Access article under the terms of the Creative Commons Attribution License

(http://creativecommons.org/licenses/by/4.0). Please note that the reuse, redistribution and reproduction in particular requires that the authors and source are credited.

The license is subject to the Beilstein Journal of Organic Chemistry terms and conditions:

(https://www.beilstein-journals.org/bjoc)

The definitive version of this article is the electronic one which can be found at:

$\underline{\text { doi:10.3762/bjoc. } 16.156}$ 